\title{
The nature of organic carbon in density-fractionated sediments in the Sacramento-San Joaquin River Delta (California)
}

\author{
S. G. Wakeham ${ }^{1}$ and E. A. Canuel ${ }^{2}$ \\ ${ }^{1}$ Skidaway Institute of Oceanography, The University of Georgia, 10 Ocean Science Circle, Savannah, GA 31411, USA \\ ${ }^{2}$ Virginia Institute of Marine Science, College of William and Mary, P.O. Box 1346, Gloucester Point, VA 23062, USA \\ Correspondence to: S. G. Wakeham (stuart.wakeham@ @skio.uga.edu)
}

Received: 28 August 2015 - Published in Biogeosciences Discuss.: 1 October 2015

Revised: 22 December 2015 - Accepted: 14 January 2016 - Published: 2 February 2016

\begin{abstract}
Rivers are the primary means by which sediments and carbon are transported from the terrestrial biosphere to the oceans but gaps remain in our understanding of carbon associations from source to sink. Bed sediments from the Sacramento-San Joaquin River Delta (CA) were fractionated according to density and analyzed for sediment mass distribution, elemental ( $\mathrm{C}$ and $\mathrm{N})$ composition, mineral surface area, and stable carbon and radiocarbon isotope compositions of organic carbon (OC) and fatty acids to evaluate the nature of organic carbon in river sediments. OC was unevenly distributed among density fractions. Mass and OC were in general concentrated in mesodensity (1.6-2.0 and $2.0-2.5 \mathrm{~g} \mathrm{~cm}^{-3}$ ) fractions, comprising $84.0 \pm 1.3 \%$ of total sediment mass and $80.8 \pm 13.3 \%$ of total OC (TOC). Low-density $\left(<1.6 \mathrm{~g} \mathrm{~cm}^{-3}\right)$ material, although rich in OC $(34.0 \pm 2.0 \%$ OC) due to woody debris, constituted only $17.3 \pm 12.8 \%$ of TOC. High-density $\left(>2.5 \mathrm{~g} \mathrm{~cm}^{-3}\right)$ organicpoor, mineral-rich material made-up $13.7 \pm 1.4 \%$ of sediment mass and $2.0 \pm 0.9 \%$ of TOC. Stable carbon isotope compositions of sedimentary OC were relatively uniform across bulk and density fractions $\left(\delta^{13} \mathrm{C}-27.4 \pm 0.5 \%\right.$ ) . Radiocarbon content varied from $\Delta{ }^{14} \mathrm{C}$ values of -382 (radiocarbon age $3800 \mathrm{yr} \mathrm{BP}$ ) to $+94 \%$ (modern) indicating a mix of young and old OC. Fatty acids were used to further constrain the origins of sedimentary OC. Short-chain $n$ - $\mathrm{C}_{14}-n$ $\mathrm{C}_{18}$ fatty acids of algal origin were depleted in ${ }^{13} \mathrm{C}\left(\delta^{13} \mathrm{C}\right.$ -37.5 to $-35.2 \%$ o but were enriched in ${ }^{14} \mathrm{C}\left(\Delta^{14} \mathrm{C}>0\right)$ compared to long-chain $n-\mathrm{C}_{24}-n-\mathrm{C}_{28}$ acids of vascular plant origins with higher $\delta^{13} \mathrm{C}(-33.0$ to $-31.0 \%$ ) but variable $\Delta^{14} \mathrm{C}$ values $(-180$ and $61 \%$ ). These data demonstrate the potentially complex source and age distributions found
\end{abstract}

within river sediments and provide insights about sediment and organic matter supply to the Delta.

\section{Introduction}

Rivers are the major conduits of sediment and organic carbon (OC) carried from upland erosional areas to lowland floodplains and estuaries and the coastal ocean (Milliman and Farnsworth, 2011). During transport, sediment grains are eroded, remobilized, winnowed, and redeposited, resulting in the sorting or mixing of material from different sources and with different reactivities and ages (Prahl, 1985; Hedges and Keil, 1995; Bianchi et al., 2007). Hydrodynamic sorting by particle size, shape and density influences transport of particles and associated materials in rivers, estuaries, and continental margins. Density, grain size, mineralogy, and organic carbon characteristics of riverine sediment grains will determine whether they are eroded and transported as suspended or bed load or deposited, and how particles cycle between phases (Jepson et al., 1997; Hassanzadeh, 2012).

Interactions between minerals and $\mathrm{OC}$ influence the fate and distribution of organic materials in soils and aquatic sediments (Hedges and Keil, 1995; Hedges and Oades, 1997; Baldock and Skjemstad, 2000; Trumbore, 2009; Rühlmann and Berhe, 2014; Keil and Mayer, 2014). Evidence on organic matter-mineral associations from soils and marine sediments shows relationships between OC concentrations and compositions, mineral surface area, physical distributions of OC on minerals, and OC preservation (Keil et al., 1994a, b; Mayer, 1994a; Ransom et al., 1998; Mayer et al., 2004; Trumbore, 2006; Keil and Mayer, 2014). Particle size and 
density are also important characteristics when considering OM composition, reactivity and the fate of soil and sediment OC. In aquatic environments, OC associated with mineral grains strongly affects flocculation of suspended aquatic particles and the cohesion of bottom sediments. OC that is intimately associated with the clay fraction is most extensively altered diagenetically, whereas larger size or higher density mineral fractions are less altered (e.g., Keil et al., 1994a; Bergamaschi et al., 1997; Wakeham et al., 2009). Trends across size and density classes and between different depositional environments show that a small fraction of the OC is present as distinct organic debris, but associations of OC with mineral surfaces are consistent with selective partitioning of OC to mineral surfaces (Keil et al., 1998; Keil and Mayer, 2014).

Chemical analysis of size-sorted sediments has been extensively used to show that compositional differences between grain sizes are related to source, diagenesis, and mineralogy (e.g., Keil et al., 1998; Bergamaschi et al., 1997; Dickens et al., 2006). Density fractionation, although much less widely utilized, takes advantage of density differences between organic matter $\left(\sim 1 \mathrm{~g} \mathrm{~cm}^{-3}\right)$ and mineral grains $\left(\geq 2.5 \mathrm{~g} \mathrm{~cm}^{-3}\right.$ ) (Mayer et al., 2004; Rühlmann et al., 2006) and by isolating organic-mineral aggregates having different organic matter loadings offers a different view of relationships between OC and particle grains. Densities of soils and sediments depend on the compositions and proportions of both organic and mineral components. Mineral-rich/organicpoor soils and sediments typically have densities over the range of $\sim 2.4-2.9 \mathrm{~g} \mathrm{~cm}^{-3}$; mineral-poor/organic-rich soils and sediments have densities between $\sim 1.0$ and $1.5 \mathrm{~g} \mathrm{~cm}^{-3}$ (Adams, 1973; Rühlmann et al., 2006).

Density fractionation has been widely used on soils to elucidate mechanisms of how organic matter is physically and chemically associated with minerals and to estimate stability, residence and turnover times of organic matter (e.g., Golchin et al., 1994; Hedges and Oades, 1997; Baldock and Skjemstad, 2000; Baisden et al., 2002a; Sollins et al., 2006; Rühlmann et al., 2006; Crow et al., 2007; Castanha et al., 2008; Trumbore, 2009; Cerli et al., 2012; Kaiser and Berhe, 2014). The chemistry, stable and radiocarbon isotopic compositions, and turnover times for isolated fractions is particularly dependent on methodology. Protocols for dispersing soil aggregates as a function of density for purposes of characterizing organic matter/mineral interactions and ecological function differ considerably, from shaking to ultrasonication at varying energy levels and with or without acid/base hydrolysis of the high-density fraction(s). Overall, soils tend to be compositionally (physically, chemically, and biologically) more complex than sediments (Keil and Mayer, 2014).

Density fractionation has been applied less often to aquatic sediments. In the few continental margin sediments that have been studied by density fractionation, most of the mass and most of the OC is found in a so-called "mesodensity" fraction, roughly defined operationally as between 1.6 and
$2.5 \mathrm{~g} \mathrm{~cm}^{-3}$ (Bock and Mayer, 2000; Arnarson et al., 2001, 2007; Dickens et al., 2006; Wakeham et al., 2009) that is rich in organic-mineral aggregates. Lower density material is largely mineral-free organic detritus, whereas higher density material is mostly organic-poor mineral grains. Chemical compositions further distinguish these fractions (reviewed by Keil and Mayer, 2014). Amino acids that are typically enriched in fine-grained and meso-density fractions point to preferential association of nitrogenous material with clays and extensive alteration of organic matter. Enrichment of carbohydrates in fine-grained fractions suggests that they help to hold aggregates together. Lignin is typically associated with larger grains or low-density material consistent with higherplant origins.

River sediments, which are largely sourced from soils, are poorly represented among aquatic environments that have been investigated. Here we used density fractionation in a pilot study to examine relationships between organic matter and mineral grains in several river sediments. In particular, we wished to better understand whether and to what extent redistributions of OC, potentially via hydrodynamic sorting, occur between rivers and the ocean, at the river-ocean interface. We determined mass, elemental $(\mathrm{C}$ and $\mathrm{N})$, and surface area distributions among density sorted fractions from five bed sediments within the Sacramento-San Joaquin River delta (hereafter termed the Delta). Stable carbon and radiocarbon isotopic compositions of bulk sediments, density fractions and isolated fatty acids were used to characterize the provenance and age of the $\mathrm{OC}$ in these sediments.

\section{Methods}

\subsection{Study area and samples}

The Sacramento-San Joaquin Delta is part of San Francisco Bay system. The Delta is a complex network of natural and man-made channels and islands, making it one of the 60 largest river deltas in the world, at $1.7 \times 10^{5} \mathrm{~km}^{2}$ and accounting for $\sim 40 \%$ of California's land area (Herbold and Moyle, 1989; Jassby and Cloern, 2000; Schoellhamer et al., 2012). As such, it is one of the most highly modified and managed systems in the world (Jassby and Cloern, 2000) and is unique ecologically in North America (Herbold and Moyle, 1989). Precipitation (rainfall and snowmelt) in the Sierra Nevada Mountains contributes most of the freshwater delivered to the Delta, with the Coast Range dividing the water flow between the Sacramento River draining into the northern half of the Central Valley and the San Joaquin River draining into the southern half. The Sacramento and San Joaquin Rivers join in the Delta and flow into northern San Francisco Bay. The Sacramento River contributes $80 \%$ of the freshwater delivered to San Francisco Bay and the San Joaquin River adds an additional $15 \%$ (Conomos et al., 1985). The Sacramento River presently delivers approx- 
imately seven times the sediment load of the San Joaquin River, mostly as suspended sediment, but sediment loads are highly episodic and significant transport of bed load occurs during floods. Sedimentation in reservoirs behind the many dams has reduced overall sediment transport since the 1950s (Wright and Schoellhamer, 2004, 2005). The narrow mouth of the Delta enhances deposition of sediments within the Delta, along the Sacramento River and in Suisun Bay, rather than in the open waters of upper San Francisco Bay.

In this study we investigate relationships between OC and density fractions in river bed sediments at five sites in the Sacramento-San Joaquin Delta (Fig. 1) system during a low freshwater discharge period in Summer 2005. Average freshwater discharge of the Sacramento River at Freeport ranged from 546.5 to $600.3 \mathrm{~m}^{3} \mathrm{~s}^{-1}$ during the sampling period and discharge of the San Joaquin River at Vernalis was 155.7 to $171.3 \mathrm{~m}^{3} \mathrm{~s}^{-1}$ (US Geological Survey). The sites were chosen to represent different sub-habitats within the Delta (e.g., upper and lower Sacramento River (Elk Slough and Horseshoe Bend, respectively), San Joaquin River (Potato Slough and Venice Cut), and Suisun Marsh (Nurse Slough)). Surface sediments $(0-5 \mathrm{~cm})$ were obtained by grab sampling. Elk Slough, Venice Cut, and Horseshoe Bend have contemporary sedimentation rates of $1.1,3.5$, and $3.5 \mathrm{~cm} \mathrm{yr}^{-1}$, respectively (Canuel et al., 2009). Nurse Slough is a tidal slough in Suisun Marsh. Suisun Marsh consists of $240 \mathrm{~km}^{2}$ of tidal and managed brackish water wetlands and $120 \mathrm{~km}^{2}$ of bays and sloughs and is the largest contiguous estuarine marsh remaining on the west coast of the US, constituting more than $10 \%$ of California's remaining natural wetlands.

\subsection{Density fractionation}

Sodium metatungstate solutions (Arnarson and Keil, 2001; Wakeham et al., 2009) with densities of 1.6, 2.0, and $2.5 \mathrm{~g} \mathrm{~cm}^{-3}$ were used sequentially to yield four density fractions: $<1.6,1.6$ to $2.0,2.0$ to 2.5 , and $>2.5 \mathrm{~g} \mathrm{~cm}^{-3}$. These fractions have been used previously (Bock and Mayer, 2000; Arnarson and Keil, 2001, 2007) for studies of sediments. The fraction with density $<1.6 \mathrm{~g} \mathrm{~cm}^{-3}$ is primarily organicrich biogenic material, the $>2.5 \mathrm{~g} \mathrm{~cm}^{-3}$ fraction is unaggregated mineral grains, and the middle density fractions are aggregates of organic matter and mineral grains. Roughly $20 \mathrm{~g}$ of wet sediment was dispersed in the $1.6 \mathrm{~g} \mathrm{~cm}^{-3}$ solution in $85 \mathrm{~mL}$ centrifuge tubes by gentle shaking on a shaker table for $30 \mathrm{~min}$. Gentle shaking rather than sonication was used to minimize disaggregation of aggregates (note differences with investigations of soils as described below). Following shaking, solutions were centrifuged for $20 \mathrm{~min}$ at 20000 relative centrifugal force. Particles at the surface of the solution were carefully removed by pipet, deposited on a $0.5 \mu \mathrm{m}$ PTFE membrane filter and washed with distilled water. This process was repeated until no additional lowdensity $\left(<1.6 \mathrm{~g} \mathrm{~cm}^{-3}\right)$ particles could be recovered (approximately 10 repetitions). The next solution, $2.0 \mathrm{~g} \mathrm{~cm}^{-3}$, was

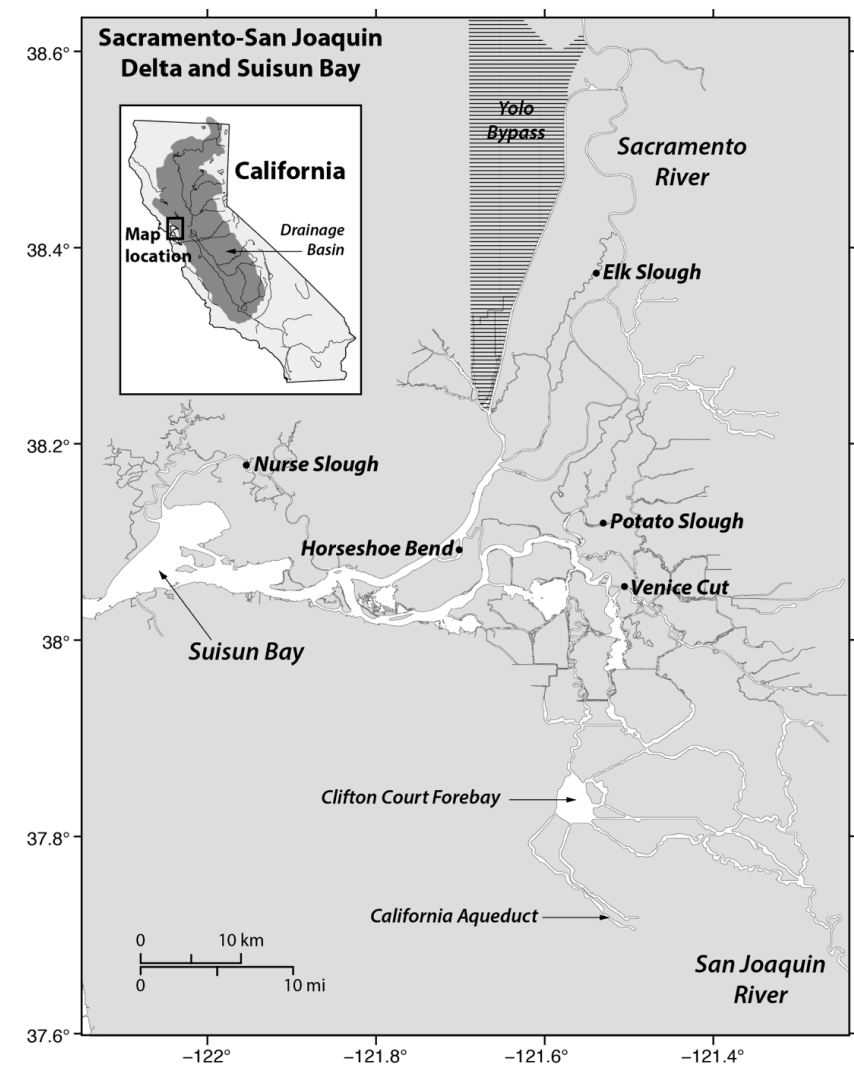

Figure 1. Map of sampling locations in the Sacramento-San Joaquin River Delta.

then added and the process repeated. Following each step, the collected particles were rinsed from the PTFE filter into $85 \mathrm{~mL}$ centrifuge tubes and washed repeatedly with distilled water to remove any remaining sodium metatungstate. Fractionated sediments were freeze-dried for further analyses.

Most protocols employed to fractionate soils involve some degree of dispersion, usually ultrasonication, and generally yield a floating (light) fraction that contains mainly plant debris, an intermediate fraction of fine organic particles that has been released by disruption (e.g., ultrasonication with or without hydrolysis) of aggregates, and a heavy residual fraction of OC strongly bound to minerals (e.g. Golchin et al., 1994; Cerli et al., 2012; Kaiser and Berhe, 2014). The fractionation scheme we and others have used for sediments is less energetic or disruptive (at least in the latter stages) than commonly used for soils and these methodological contrasts need to be considered when comparing results.

Metatungstate solutions can solubilize organic matter from the soil and/or sediment grains (Shang and Tiessen, 2001; Crow et al., 2007; Castanha et al., 2008). OC solubilization apparently increases with the density of the metatungstate solution used and may range between 10 and $28 \%$ of bulk OC regardless of whether the treatment involved shaking with gravimetric settling or sonication and centrifugation. A slight 
(a)

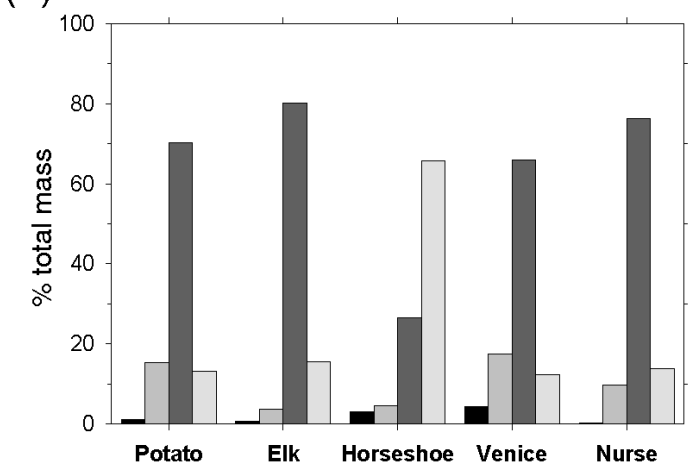

(c)

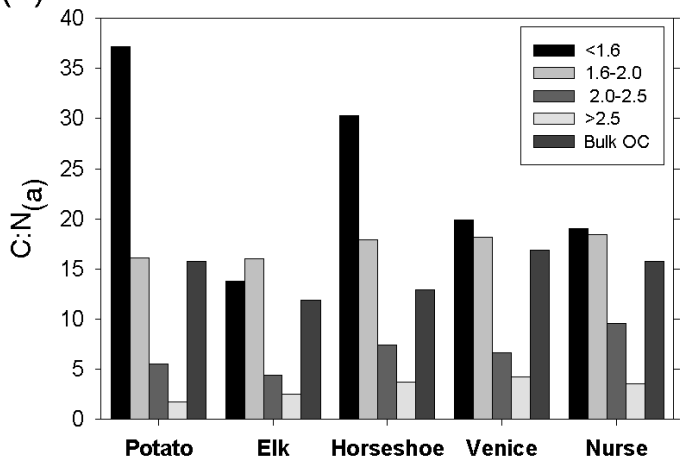

(b)

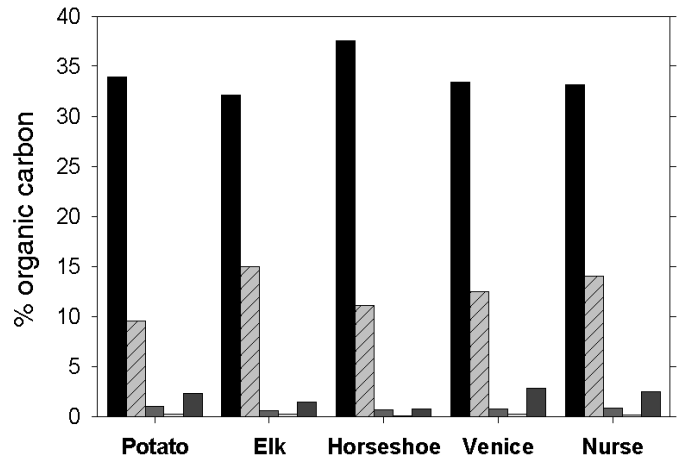

(d)

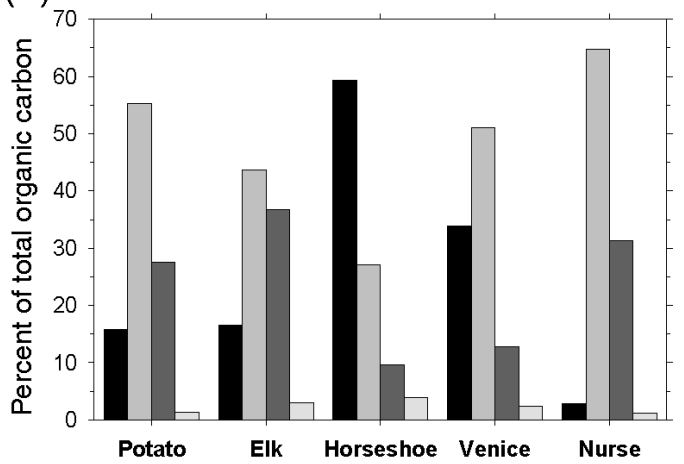

Figure 2. Distributions of (a) mass, (b) organic carbon content, (c) atomic $\mathrm{C}: \mathrm{N}$ ratio, and (d) percent of total organic carbon for the Delta sediment bulk and density fractions.

yellowing of the solutions used here attests to dissolution of OC to some extent, but we did not specifically conduct mass balance measurements to quantify the extent of OC solubilization.

\subsection{Elemental analysis}

Organic carbon (\% OC) and total nitrogen (\% TN) were measured using a Fisons CHN analyzer (Model EA 1108) (Waterson and Canuel, 2008). Freeze-dried sediments were ground and acidified in pre-combusted silver capsules with $10 \%$ high purity $\mathrm{HCl}$ to remove inorganic carbon.

\subsection{Specific surface area analysis}

Specific surface area (SA) of the mineral component of each sediment fraction was measured by nitrogen adsorption using a five-point (Brunauer-Emmett-Teller (BET)) method in a Micromeritics Gemini V surface area analyzer (Waterson and Canuel, 2008). Freeze-dried but unground sediments were heated at $350^{\circ} \mathrm{C}$ for $12 \mathrm{~h}$ to remove organic matter and then degassed for $>2 \mathrm{~h}$ on a Micromeritics Flow Prep 060 degas station at $250^{\circ} \mathrm{C}$ to remove water. SA $\left(\mathrm{m}^{2} \mathrm{~g}^{-1}\right)$ and carbon: surface area ratios (OC: $\mathrm{SA} ; \mathrm{mg} \mathrm{OC} \mathrm{m}^{-2}$ ) were obtained.

\subsection{Carbon isotope analysis}

Stable carbon $\left(\delta^{13} \mathrm{C}\right)$ and radiocarbon $\left({ }^{14} \mathrm{C}\right)$ analyses were conducted at the National Ocean Sciences Accelerator Mass Spectrometer (NOSAMS) facility at Woods Hole Oceanographic Institution. Ground and acidified sediment samples were combusted to $\mathrm{CO}_{2}$ at $850{ }^{\circ} \mathrm{C}$ for $5 \mathrm{~h}$ in Vycor tubes. A split of the purified and quantified $\mathrm{CO}_{2}$ was analyzed for $\delta^{13} \mathrm{C}$ on a VG Micromass Optima isotope ratio mass spectrometer. The remaining $\mathrm{CO}_{2}$ was reduced to filamentous carbon (graphite) over either Fe or Co powder and then analyzed for radiocarbon using standard NOSAMS procedures (McNichol et al., 1994; von Reden et al., 1998).

Fatty acids (FA) were isolated from three of the bulk sediments and analyzed for ${ }^{13} \mathrm{C}$ and ${ }^{14} \mathrm{C}$ isotope values. Lipid extracts obtained by accelerated solvent extraction (ASE) using dichloromethane: methanol $(9: 1)$ were saponified, and the recovered FA were methylated with $\mathrm{BF}_{3}-\mathrm{MeOH}$. Two fatty acid methyl ester (FAME) composites were obtained by preparative capillary gas chromatography (Eglinton et al., 1997; Wakeham et al., 2006): short-chain FAME ( $n-\mathrm{C}_{14}-n$ $\left.\mathrm{C}_{18}\right)$ and long-chain FAME $\left(n-\mathrm{C}_{24}-n-\mathrm{C}_{28}\right)$. Compositions, purity, and amounts of FAME isolates were checked by gas chromatography and analyzed subsequently for ${ }^{13} \mathrm{C}$ and ${ }^{14} \mathrm{C}$. 
(a)

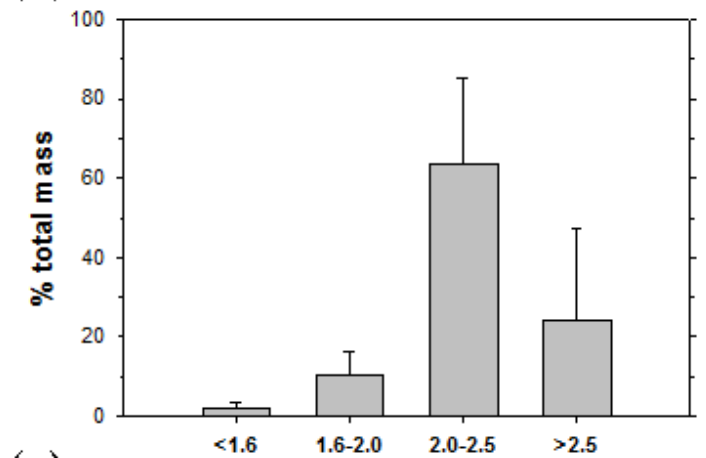

(c)

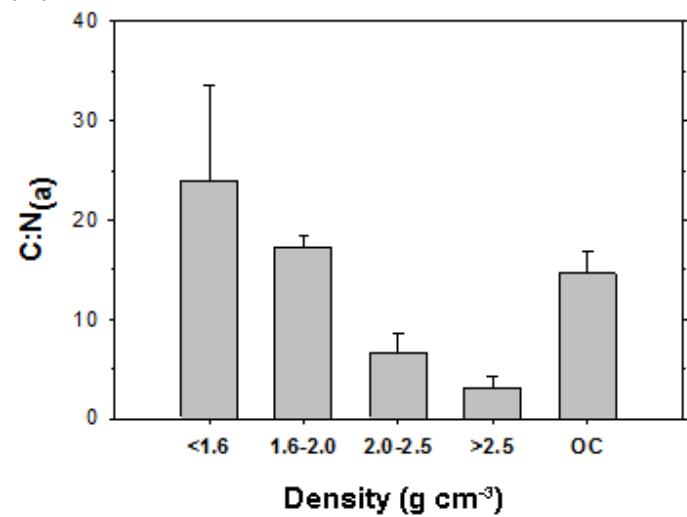

(b)

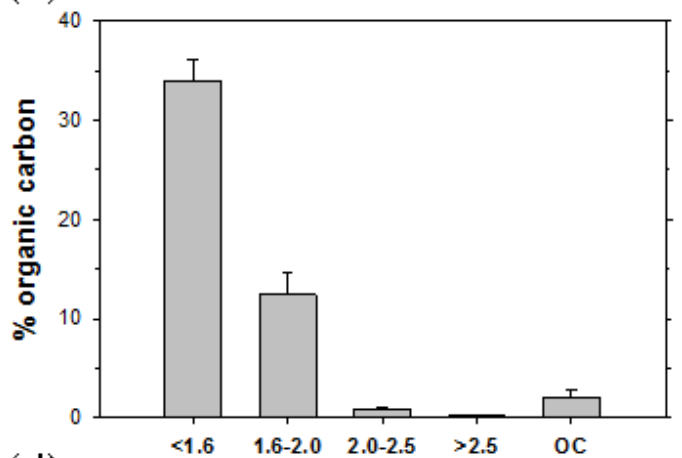

(d)

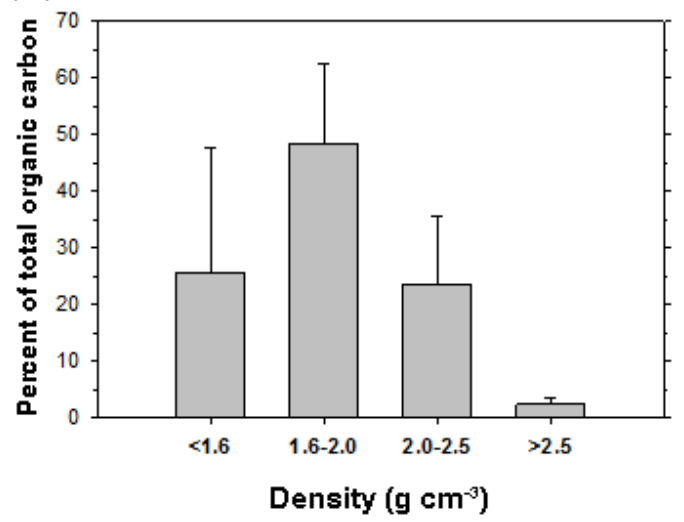

Figure 3. Mean and standard deviations of distributions of (a) mass, (b) organic carbon content, (c) atomic $\mathrm{C}: \mathrm{N}$ ratio, and (d) percent of total organic carbon for each density fractions across the five study sites.

Corrections for the addition of carbon from the methyl group during methylation were made by mass balance.

\section{Results}

\subsection{Density fractionation}

Particles in the 2.0 to $2.5 \mathrm{~g} \mathrm{~cm}^{-3}$ density range dominated four of the studied sediments (Potato Slough, Elk Slough, Venice Cut, and Nurse Slough), constituting $\sim 70-80 \%$ of total dry mass (Fig. 2a), with a mean of $73.1 \pm 6.6 \%$. Considering all five sediments, the 2.0 to $2.5 \mathrm{~g} \mathrm{~cm}^{-3}$ material accounted for between 26.5 and $80.1 \%$ of dry mass or a mean of $63.8 \pm 21.5 \%$ (Fig. 3a). The Horseshoe Bend sediment contained the greatest proportion $(\sim 66 \%)$ of mass in the high-density fraction, $>2.5 \mathrm{~g} \mathrm{~cm}^{-3}$, whereas only $\sim 30 \%$ of total mass was in the 2.0 to $2.5 \mathrm{~g} \mathrm{~cm}^{-3}$ fraction. The lowest density fraction of these sediments, $<1.6 \mathrm{~g} \mathrm{~cm}^{-3}$ material, made-up the smallest proportion of total mass, never more than a few percent $(1.6 \pm 1.9 \%)$. The 1.6 to $2.0 \mathrm{~g} \mathrm{~cm}^{-3}$ fractions varied between 4 and $17 \%$ of mass $(11.6 \pm 6.1 \%)$, and the heaviest material $\left(>2.5 \mathrm{~g} \mathrm{~cm}^{-3}\right)$ was generally less than $\sim 15 \%(13.7 \pm 1.4 \%)$.

\subsection{Elemental compositions}

Organic carbon (\% OC) of all five bulk, unfractionated sediments ranged from $0.7 \%$ at Horseshoe Bend to $2.9 \%$ at Venice Cut (Fig. 2b); mean $2.0 \pm 0.86 \%$ (Fig. 3b). Total nitrogen ( $\% \mathrm{TN}$ ) ranged from 0.07 to $0.20 \%$ in bulk sediments (mean $0.15 \pm 0.05 \%$ ). \% OC and \% TN were well correlated with one another $\left(r^{2}=0.93\right)$. Atomic $\mathrm{C}: \mathrm{N}(\mathrm{a})$ ratios ranged between 16.9 in Venice Cut to 11.9 in Elk Slough (Fig. 2c; mean $14.6 \pm 2.1 \%$, Fig. 3c). Low-density fractions had the highest $\mathrm{OC}$ and TN concentrations; highest density fractions had the lowest \% OC and \% TN. Low-density $<1.6 \mathrm{~g} \mathrm{~cm}^{-3}$ material contained between 32 and $37 \%$ OC $(34.0 \pm 2.1 \%)$ and from $1.5-2.7 \% \mathrm{TN}(1.9 \pm 0.6 \%$; data not shown). The $1.6-2.0 \mathrm{~g} \mathrm{~cm}^{-3}$ material contained $9-15 \%$ OC $(12.4 \pm 2.2 \%)$ and $0.7-1.1 \%$ TN $(0.8 \pm 0.2 \%)$; the $2.0-2.5$ and $>2.5 \mathrm{~g} \mathrm{~cm}^{-3}$ fractions both contained $<1 \%$ OC $(0.8 \pm 2.2$ and $0.2 \pm 0.1 \%$, respectively) and $<0.2 \% \mathrm{TN}$ $\left(0.2 \pm 0.04\right.$ and $0.09 \pm 0.06 \%$, respectively). $\mathrm{C}: \mathrm{N}_{(\mathrm{a})}$ ratios thus generally decreased with increasing particle density (Figs. 2c, 3c): 24 for $<1.6 \mathrm{~g} \mathrm{~cm}^{-3}, 17$ for 2.0 to $2.5 \mathrm{~g} \mathrm{~cm}^{-3}$, 6.7 for 2.0 to $2.5 \mathrm{~g}$ to 3.1 for $>2.5 \mathrm{~g} \mathrm{~cm}^{-3}$ fractions. Low $\mathrm{C}: \mathrm{N}_{(\mathrm{a})}$ ratios for the $>2.5 \mathrm{~g} \mathrm{~cm}^{-3}$ fractions may be artifacts arising from sorption of excess inorganic nitrogen onto these 

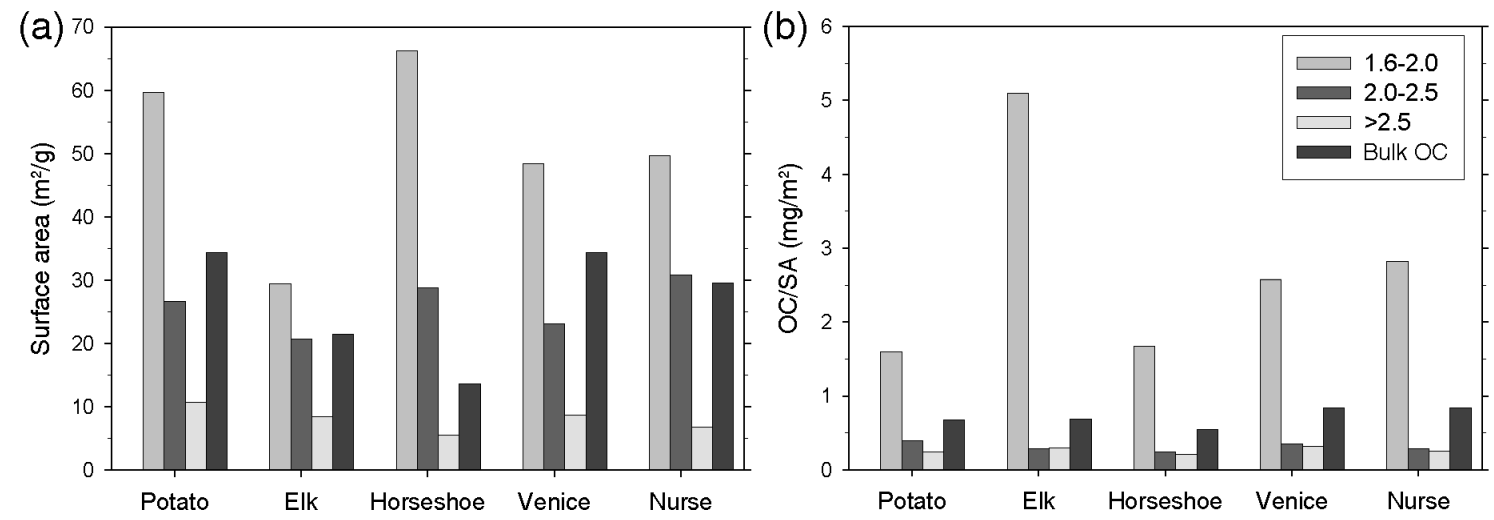

Figure 4. Surface area (SA) (following combustion) (a) and organic carbon/surface area ratio (OC/SA) (b) for Delta bulk sediment and density fractions.

particles or blanks associated with measuring low levels of nitrogen in these organic matter-poor samples.

\subsection{Specific surface area (SA) and $\mathrm{OC}$ : SA ratios}

Specific surface areas (SA) of mineral grains in bulk Delta sediments ranged from $\sim 14 \mathrm{~m}^{2} \mathrm{~g}^{-1}$ (Horseshoe Bend) to $\sim 34 \mathrm{~m}^{2} \mathrm{~g}^{-1}$ (Potato Slough) (Fig. 4a). SA was measured on three density fractions for each sediment, but not on the $<1.6 \mathrm{~g} \mathrm{~cm}^{-3}$ fractions because they contained incompletely charred plant fragments which could confound interpretations. SA decreased with increasing particle density. The 1.6 to $2.0 \mathrm{~g} \mathrm{~cm}^{-3}$ material had the highest SA of the measured fractions and SA ranged from $\sim 65 \mathrm{~m}^{2} \mathrm{~g}^{-1}$ at Horseshoe Bend to $\sim 30 \mathrm{~m}^{2} \mathrm{~g}^{-1}$ in Elk Slough. Thus in four out of five cases SA of 1.6 to $2.0 \mathrm{~g} \mathrm{~cm}^{-3}$ fractions was $\geq 50 \mathrm{~m}^{2} \mathrm{~g}^{-1}$. SA's in the 2.0 to $2.5 \mathrm{~g} \mathrm{~cm}^{-3}$ fractions were $\sim 25-30 \mathrm{~m}^{2} \mathrm{~g}^{-1}$, and in the $2.5 \mathrm{~g} \mathrm{~cm}^{-3}$ fractions were $\sim 5-10 \mathrm{~m}^{2} \mathrm{~g}^{-1}$.

Measuring SA allows calculation of an organic carbon: surface area ratio (OC: $\mathrm{SA}$ ) widely used to express the loading of sedimentary OC onto mineral grains. OC : SA ratios of bulk sediments ranged from $0.68-0.84 \mathrm{mg} \mathrm{OC} \mathrm{m}^{-2}$ (mean $0.72 \pm 0.13 \mathrm{mg} \mathrm{OC} \mathrm{m}^{-2}$; Fig. 4b). The $1.6-2.0 \mathrm{~g} \mathrm{~cm}^{-3}$ fractions consistently had the highest OC:SA ratios (1.6$5.1 \mathrm{mg} \mathrm{OC} \mathrm{m}^{-2}$, Fig. $4 \mathrm{~b}$; mean $2.8 \pm 1.4 \mathrm{mg} \mathrm{OC} \mathrm{m}^{-2}$ ). OC:SA ratios decreased with density so that for the $>2.5 \mathrm{~g} \mathrm{~cm}^{-3}$ fractions OC: SA ranged from $0.21-0.32 \mathrm{mg}$ $\mathrm{OC} \mathrm{m}^{-2}\left(0.26 \pm 0.04 \mathrm{mg} \mathrm{OC} \mathrm{m}^{-2}\right)$.

\subsection{Stable carbon and radiocarbon isotopes}

Stable carbon isotope $\left(\delta^{13} \mathrm{C}\right)$ values for bulk OC were relatively uniform and ranged between -27.5 and $-26.5 \%$ o $\left(-27.0 \pm 0.5 \%\right.$; Table 1; Fig. 5a). $\delta^{13} \mathrm{C}$ values for OC in the density fractions of the three fractionated sediments (Elk Slough, Venice Cut, and Nurse Slough) were somewhat more variable, but $\delta^{13} \mathrm{C}$ values among density fractions were always within $\pm \sim 1.5 \%$ o (Fig. 5a, Table 1). $\delta^{13} \mathrm{C}$ values for density fractions from Elk Slough were lower than those from Venice Cut and Nurse Slough. Low-density material tended to have lower $\delta^{13} \mathrm{C}$ values ( $\sim 1$ to $1.5 \%$ o lower) than higher density fractions.

Radiocarbon compositions were quite variable, reflecting a wide range of carbon ages (Fig. 5b; Table 1). $\Delta^{14} \mathrm{C}$ is defined by Stuiver and Pollach (1977) and Stuiver (1980) where $\Delta^{14} \mathrm{C}$ values $\geq 0$ are completely modern $\mathrm{OC}$ and reported as "modern"; $\Delta{ }^{14} \mathrm{C}$ values $<0$ indicate the presence varying proportions of old carbon. "Modern" is conventionally defined as $95 \%$ of the ${ }^{14} \mathrm{C}$ activity of an oxalic acid standard for AD 1950 (Karlen et al., 1964). The fraction of carbon in a sample that is modern, $f_{\mathrm{m}}$, ranges from $f_{\mathrm{m}}$ values $>1$ (if ${ }^{14} \mathrm{C}$ from atmospheric nuclear bomb testing is present) to 0 (containing no measurable ${ }^{14} \mathrm{C}$ ). Ages are calculated using 5568 years as the half-life of radiocarbon. Bulk OC from Elk Slough was modern in age $\left(\Delta^{14} \mathrm{C}+3.4 \%\right.$ ). Mesodensity (1.6 to $2.0 \mathrm{~g} \mathrm{~cm}^{-3}$ and 2.0 to $2.5 \mathrm{~g} \mathrm{~cm}^{-3}$ ) fractions from Elk Slough were enriched in ${ }^{14} \mathrm{C}$ $\left(\Delta^{14} \mathrm{C}+94\right.$ and $+89 \%$, respectively) relative to bulk sediment $\mathrm{OC}$, whereas the $>2.5 \mathrm{~g} \mathrm{~cm}^{-3}$ material was depleted in ${ }^{14} \mathrm{C}(-25 \%)$ relative to both $\mathrm{OC}$ and mesodensity material. In contrast, bulk OC from Venice Cut and Nurse Slough was depleted in ${ }^{14} \mathrm{C}\left(\Delta^{14} \mathrm{C}-151\right.$ and $-161 \%$ o, respectively), as were the density fractions. In both Venice Cut and Nurse Slough, $>2.5 \mathrm{~g} \mathrm{~cm}^{-3}$ fractions were highly depleted in ${ }^{14} \mathrm{C}$ $\left(\Delta^{14} \mathrm{C}-339\right.$ and $-382 \%$ for Venice Cut and Nurse Slough, respectively), whereas the remaining density fractions and bulk sediment were remarkably uniform (average $\Delta^{14} \mathrm{C}$ of $-156 \pm 39 \%$ ).

Fatty acids (FA) were isolated from bulk (unfractionated) sediments and analyzed for stable carbon and radiocarbon content to help constrain the provenance and age of OC in the sediments. As constituents of many energy storage and structural membrane lipids in organisms, FA feature structural differences between compounds biosynthesized by algae, bacteria, and higher plants that make them biomark- 

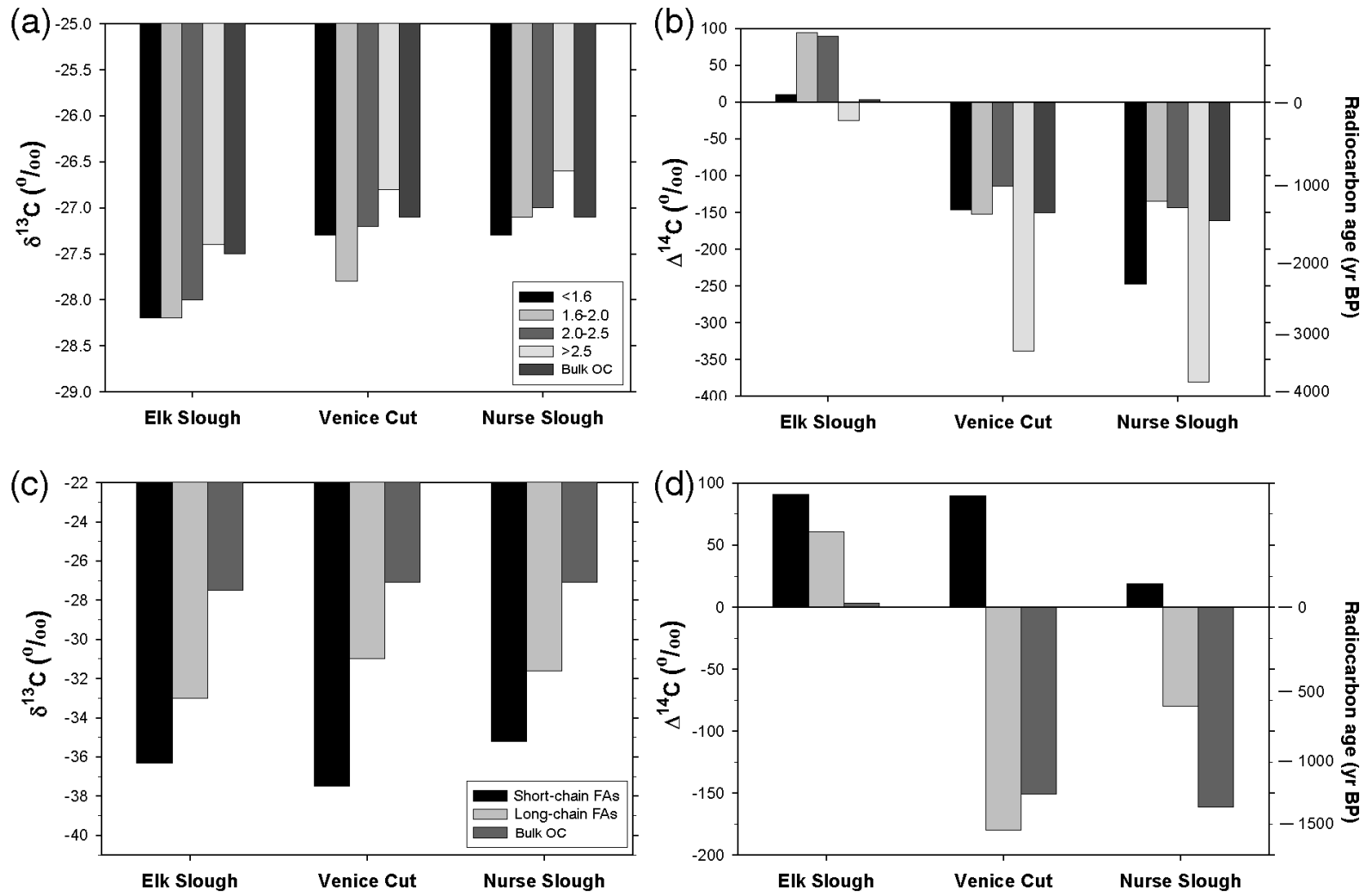

Figure 5. $\delta^{13} \mathrm{C}$ (a) and $\Delta^{14} \mathrm{C}$ (b) values for OC in Delta bulk sediment and density fractions and $\delta^{13} \mathrm{C}(\mathbf{c})$ and $\Delta^{14} \mathrm{C}(\mathbf{d})$ values for fatty acids in bulk sediments.

ers for elucidating the origins and diagenetic fate of organic matter in sediments (Volkman, 2006; Wakeham et al., 1997). FA distributions in the Delta river sediments were bimodal: short-chain $n-\mathrm{C}_{14}-n-\mathrm{C}_{18}$ compounds peaking at $n-\mathrm{C}_{16}$ and long-chain $n-\mathrm{C}_{24}-n-\mathrm{C}_{28}$ FA peaking at $\mathrm{C}_{24}$. Short-chain FA had lower $\delta^{13} \mathrm{C}$ values $(-37.5$ to $-35.2 \%$; Fig. $5 \mathrm{c})$ compared to long-chain FA ( -33.0 to $-31.0 \%$ o). FA were significantly depleted in ${ }^{13} \mathrm{C}$ relative to total $\mathrm{OC}$ reflecting contributions from other organic compounds to $\mathrm{OC}$ such as amino acids and carbohydrates that are enriched in ${ }^{13} \mathrm{C}$ compared to lipids. Short-chain FA in all three fractionated sediments were modern $\left(\Delta^{14} \mathrm{C}>0\right.$; Fig. $\left.5 \mathrm{~d}\right)$. While the radiocarbon age for long-chain FA in Elk Slough was also modern (61\%o), $\Delta^{14} \mathrm{C}$ values in Venice Cut and Nurse Slough were lower indicating that FA at these locations were older in age $(-180$ and $-80 \%$, respectively).

\section{Discussion}

\subsection{Particle morphology}

Previous studies have shown scanning electron microscopy (SEM) to be valuable for examining particle morphology of density-fractionated sediments (photomicrographs of density fractions are shown in Bock and Mayer, 2000; Arnarson and Keil, 2001, 2007; Wakeham et al., 2009). We do not have SEM images of the density fractions in this study but observations from the previous studies are relevant here. Lowdensity $<1.6 \mathrm{~g} \mathrm{~cm}^{-3}$ fractions typically contain readily identifiable filaments and particles resembling terrestrial wood fragments or aggregates containing plant debris. Aggregates of up to a millimeter in size are common, as well as smallersized particles. The abundance of plant material in lowdensity material is borne out by the high OC concentrations and, when measured, high lignin concentrations (Sampere et al., 2008; Wakeham et al., 2009; Schreiner et al., 2013). Mesodensity ( 1.6 to 2.0 and 2.0 to $2.5 \mathrm{~g} \mathrm{~cm}^{-3}$ ) fractions contain aggregates that survived the density fractionation process, but the size and abundance of aggregates decreases as density increases. The highest density $\left(>2.5 \mathrm{~g} \mathrm{~cm}^{-3}\right)$ fractions are primarily unaggregated mineral grains, often only a few micrometers in size. Arnarson and Keil (2001) also examined the mineral content of density fractions of a sediment from the oxygen minimum zone off the west coast of Mexico by X-ray photoelectron spectroscopy. Low-density and OC-rich material was dominated by clay minerals whereas the high-density OC-poor fraction was dominated by quartz and feldspars. It is impossible to rule out some alteration of particle morphology during the fractionation treatment, but 
Table 1. Stable and radiocarbon isotope data for OC in density fractions, bulk OC and fatty acids for Elk Slough, Venice Cut and Nurse Slough sediments.

\begin{tabular}{|c|c|c|c|c|c|c|}
\hline & $\delta^{13} \mathrm{C}(\% \circ)$ & $\Delta^{14} \mathrm{C}(\% \circ)$ & $f_{\mathrm{m}}$ & $f_{\mathrm{m} \text { error }}$ & Age (yr BP) & Age Error \\
\hline \multicolumn{7}{|c|}{ Elk Slough } \\
\hline$<1.6$ & -28.2 & 10 & 1.017 & 0.0039 & modern & \\
\hline $1.6-2.0$ & -28.2 & 94 & 1.101 & 0.0043 & modern & \\
\hline $2.0-2.5$ & -28.0 & 89 & 1.097 & 0.0034 & modern & \\
\hline$>2.5$ & -27.4 & -25 & 0.982 & 0.0042 & 150 & 35 \\
\hline bulk & -27.5 & 3.4 & 1.010 & 0.0031 & modern & \\
\hline Short FA & -36.3 & 91 & 1.100 & 0.0072 & modern & \\
\hline Long FA & -33.0 & 61 & 1.069 & 0.0091 & modern & \\
\hline \multicolumn{7}{|c|}{ Venice Cut } \\
\hline$<1.6$ & -27.3 & -147 & 0.859 & 0.0027 & 1220 & 25 \\
\hline $1.6-2.0$ & -27.8 & -152 & 0.854 & 0.0028 & 1270 & 25 \\
\hline $2.0-2.5$ & -27.2 & -114 & 0.892 & 0.0037 & 920 & 35 \\
\hline$>2.5$ & -26.8 & -339 & 0.666 & 0.0029 & 3270 & 35 \\
\hline bulk & -27.1 & -151 & 0.854 & 0.0037 & 1260 & 35 \\
\hline Short FA & -37.5 & 90 & 1.099 & 0.0097 & modern & \\
\hline Long FA & -31.0 & -180 & 0.825 & 0.0097 & 1840 & 100 \\
\hline \multicolumn{7}{|c|}{ Nurse Slough } \\
\hline$<1.6$ & -27.3 & -247 & 0.758 & 0.0029 & 2230 & 30 \\
\hline $1.6-2.0$ & -27.1 & -135 & 0.871 & 0.0027 & 1110 & 25 \\
\hline $2.0-2.5$ & -26.9 & -144 & 0.862 & 0.0033 & 1190 & 30 \\
\hline$>2.5$ & -26.6 & -382 & 0.622 & 0.0026 & 3810 & 30 \\
\hline bulk & -27.1 & -161 & 0.845 & 0.0032 & 1350 & 30 \\
\hline Short FA & -35.2 & 19 & 1.027 & 0.0056 & modern & \\
\hline Long FA & -31.6 & -80 & 0.927 & 0.0097 & 915 & 85 \\
\hline
\end{tabular}

Arnarson and Keil (2001) suggest that the degree of sample handling used here does not significantly disrupt the "organic glue" that holds aggregates together. Indeed, Bock and Mayer (2000) had previously proposed that removal of this organic binder, such as by the combustion step used in SA analysis, is required for organic-mineral particles to disaggregate.

\subsection{Organic carbon among density fractions}

In previous studies, bed sediments of the Lower Sacramento River were found to have a mean OC content of $0.55 \%$ (range $0.14-2.1 \%$ ) and in the lower San Joaquin River a mean OC of $0.68 \%(0.26-1.38 \%)$ (Reed, 2002; Nilsen and Delaney, 2005). The bulk sediments in our study had somewhat higher TOC contents (mean $2.0 \pm 0.9 \%$, range $0.7-2.9 \%)$. TOC of the density fractions were lower than bulk sediments for high-density fractions $(0.8 \pm 0.2 \%$ OC for 2.0 to $2.5 \mathrm{~g} \mathrm{~cm}^{-3}$ and $0.2 \pm 0.07 \%$ OC for $>2.5 \mathrm{~g} \mathrm{~cm}^{-3}$ fractions, respectively) and higher for low-density fractions $\left(34.0 \pm 2.1 \%\right.$ OC for $<1.6 \mathrm{~g} \mathrm{~cm}^{-3}$ and $12.4 \pm 2.1 \%$ OC for 1.6 to $2.0 \mathrm{~g} \mathrm{~cm}^{-3}$ fractions). The 1.6 to $2.0 \mathrm{~g} \mathrm{~cm}^{-3}$ fractions therefore made-up the greatest proportions of TOC (44-65\%; mean $53.7 \pm 8.8 \%$ of TOC; Figs. $2 \mathrm{~d}$ and $3 \mathrm{~d}$ ), re- flecting the high proportion this density fraction contributed to total sediment mass despite low OC concentrations. The 2.0 to $2.5 \mathrm{~cm}^{-3}$ fractions contained $13-37 \%$ of TOC (mean $27.1 \pm 10.3 \%$ of TOC). Collectively, mesodensity material (1.6 to $2.0 \mathrm{~g} \mathrm{~cm}^{-3}$ plus 2.0 to $2.5 \mathrm{~g} \mathrm{~cm}^{-3}$ fractions) constituted the highest proportions of TOC, $63-96 \%$ (mean $80.8 \pm 13.3 \%$ of TOC).

This dominance of mesodensity material, in terms of both mass and OC content, is common among river (lower Mississippi River) and coastal sediments (Mississippi Margin, Washington Margin, Mexico Margin) that have been investigated by density fractionation (Bock and Mayer, 2000; Arnarson et al., 2001; Dickens et al., 2006; Wakeham et al., 2009). The Sacramento-San Joaquin Delta sediments therefore were generally consistent with previous studies in coastal regions. The Horseshoe Bend sediment was somewhat different from the other four sediments studied here in that OC-poor high-density $>2.5 \mathrm{~g} \mathrm{~cm}^{-3}$ material $(65 \%$ of mass but only $4 \%$ of TOC) was most abundant, with only $30 \%$ of mass and $37 \%$ of TOC in the mesodensity fractions. This sediment is similar to sediments off the Eel River on the California Margin and in the Colville River Delta in the Alaskan Beaufort Sea where erosive hydrodynamic winnow- 
ing leaves behind greater proportions of denser, sandy material (Wakeham et al., 2009; Schreiner et al., 2013). Horseshoe Bend flows along the eastern and southern edges of Decker Island, and is the original Sacramento River channel. Higher density sediments with low OC content at Horseshoe Bend are consistent with hydrodynamic winnowing by Sacramento River flow and/or tidal currents from San Francisco Bay.

\subsection{Physical character of sediment particles}

Sediment transport through the Delta, and deposition in the upper San Francisco Bay estuary, has varied considerably over the past century. The high sediment loads from hydraulic mining during the later 1800s and early 1900s (up to a 9-fold increase over the pre-mining period) have dropped significantly due to water management projects such as dams, levees, and bypass channels (Schoellhamer et al., 2012) and adjustment to a regime of decreasing sediment supply during the 20th century (Schoellhamer et al., 2013). Bed sediments in channels of the lower Sacramento River are 8-50\% (mean $19 \%$ ) fines $(<63 \mu \mathrm{m})$ and in the San Joaquin River are 15-79\% (mean $48 \%$ ) fines (Schoellhamer et al., 2012), and as noted above TOC contents are $0.14-2.1 \%$. Larger floods and increased winnowing of fine grains from the bed sediments in the Sacramento River are the probable cause for differences between the two rivers. During large floods, the sand content of bed sediments often approaches $100 \%$ in the Sacramento River, whereas during intervals between floods, sediments become finer.

\subsection{Specific surface area OC loadings on sediment grains}

Sediment grain size, particle shape, density, mineralogy, and organic carbon content determine how particles behave in rivers and on coastal margins (Bridge and Bennett, 1992; Dade and Friend, 1998; Hassanzadeh, 2012) and their nutritional value to organisms (Mayer et al., 1993). Specific mineral surface area (SA) of sediment particles is often thought of as an approximate (inverse) proxy for grain size (Horowitz and Elrick, 1987; Keil et al., 1994a; Bergamaschi et al., 1997). In general, as grain size decreases, SA and \% OC increase. But this relationship is probably simplistic since surface roughness of mineral particles may cause SA to be considerably higher than predicted by grain size alone (Weiler and Mills, 1965; Mayer, 1994a, b), and SA measured after combustion that may destroy larger organic particles or organic-mineral aggregates likely under-represents the true size of the original aggregates. Inorganic coatings, notably $\mathrm{Fe}$ and Mn oxides, also help to cement fine-grained particles into water-stable aggregates of larger size (Horowitz and Elrick, 1987), decreasing effective SA. In the present study, SA was measured on all five bulk sediments and three density fractions of each sediment to evaluate the degree of OC loading (OC: SA) onto different density fractions, analogous to the more common measurements of SA and OC : SA of sediment particles of different grain sizes. SA decreased with increasing particle density (Fig. 4a), suggesting that higher density fractions were characterized by larger particle grain sizes (the $<1.6 \mathrm{~g} \mathrm{~cm}^{-3}$ fractions being exceptions). Higher SA for the intermediate density fractions (e.g., 1.6 to $2.0 \mathrm{~g} \mathrm{~cm}^{-3}$ ) are similar to previous observations (Arnarson and Keil, 2001, 2007; Wakeham et al., 2009) and might result from rough three-dimensional structures of aggregated clay grains (Hodson et al.,1998). In contrast, quartz and feldspar grains that dominate the high-density fractions have low SA.

Organo-mineral associations affect $\mathrm{OC}$ reactivity and $\mathrm{OC}$ sorbed onto mineral grains is protected from degradation (Mayer, 1999; Hedges and Keil, 1995; Keil and Mayer, 2014). Lower OC: $\mathrm{SA}$ ratios in deltaic $\left(\sim 0.3 \mathrm{mg} \mathrm{OC} \mathrm{m}^{-2}\right)$ and deep-sea sediments $\left(\sim 0.15 \mathrm{mg} \mathrm{OC} \mathrm{m}^{-2}\right)$ indicate desorption or losses of OC from mineral grains due to microbial decomposition whereas higher OC:SA ratios $(\geq 2 \mathrm{mg}$ $\mathrm{OC} \mathrm{m}^{-2}$ ) occur typically in anoxic, marsh, and estuarine sediments where OC is preserved because supply exceeds decomposition (Keil et al., 1997). Among the river sediments discussed here, OC:SA ratios of bulk sediments were relatively invariant, between 0.54 and $0.84 \mathrm{mg} \mathrm{OC} \mathrm{m}^{-2}$, similar to OC loadings in the Amazon and Mississippi Rivers but lower than adjacent marsh and estuary sediments and higher than adjacent continental shelf sediments (Keil et al., 1997; Gordon and Goñi, 2004; Waterson and Canuel, 2008). Among density fractions in this study, OC: SA ratios were higher for 1.6 to $2.0 \mathrm{~g} \mathrm{~cm}^{-3}$ fractions than for bulk sediments $\left(2.75 \pm 1.4\right.$ vs. $0.72 \pm 0.13 \mathrm{mg} \mathrm{OC} \mathrm{m}^{-2}$, respectively) indicating more $\mathrm{OC}$ was associated with mineral material. In contrast, OC:SA were lower for the 2.0 to 2.5 and $>2.5 \mathrm{~g} \mathrm{~cm}^{-3}$ fractions $(0.31 \pm 0.06$ vs. $0.26 \pm 0.04 \mathrm{mg}$ $\mathrm{OC} \mathrm{m}^{-2}$, respectively) than bulk sediment, where less OC was associated with mineral phases.

\subsection{Provenance of $\mathrm{OC}$ in the Sacramento-San Joaquin Delta}

Sources of OC to river sediments in the Delta are diverse (Canuel, 2001). Autochthonous sources include phytoplankton ( $80 \%$ of annual TOC input), higher aquatic plants ( $18 \%$ of TOC), and benthic macroalgae $(<2 \%)$; seagrasses and seaweeds are absent (Jassby and Cloern, 2000). Allochthonous contributions, much of which are soil-derived, from riparian zones within the rivers' watersheds may come from tributaries ( $81 \%$ of TOC), agriculture $(11 \%)$, tidal marsh export (4\%), wastewater (4\%), and urban discharges $(1 \%)$. Relative contributions of each depend on river flow, which itself is seasonally variable. However, taken together, autochthonous inputs account for only about $15 \%$ of annual TOC input to the Delta, whereas allochthonous sources dominate at $85 \%$. The Jassby and Cloern (2000) model further indicates that $\sim 90 \%$ of TOC supply to Suisun Bay and northern San Francisco Bay is delivered by the Delta rivers, in 
stark contrast to south San Francisco Bay where 90\% of TOC is autochthonous.

$\mathrm{C}: \mathrm{N}_{(\mathrm{a})}$ ratios of bulk sediments confirm the importance of vascular plant $\mathrm{OC}$ and minor input of algal material to the Delta river sediments. Among density fractions, increasing $\mathrm{C}: \mathrm{N}_{(\mathrm{a})}$ ratios with decreasing density point to the importance of vascular plant $\mathrm{OC}$ in lower density fractions. Results from a wide-ranging investigation of elemental and isotope compositions of aquatic and terrestrial plants in the Delta system by Cloern et al. (2002) and studies of suspended POM (Canuel, 2001) support this conclusion.

There was considerable variability in ${ }^{13} \mathrm{C}$ isotopic composition among the plants analyzed by Cloern et al. (2002) in the Delta, with differences reflecting carbon source and carbon fixation pathway (Hayes, 2001; Pearson, 2010). Among plants fixing carbon dioxide from the atmosphere, $\mathrm{C}_{4}$ marsh plants were relatively enriched in ${ }^{13} \mathrm{C}(\sim-17$ to $-12 \%)$, whereas $\mathrm{C}_{3}$ salt marsh, floating vascular and terrestrial plants were, by comparison, depleted in ${ }^{13} \mathrm{C}(\sim-31$ to $-22 \%$ o). Aquatic filamentous algae, phytoplankton and submerged vascular plants that utilize dissolved $\mathrm{CO}_{2}$ had highly variable $\delta^{13} \mathrm{C}$ values covering most of the range given above, usually depleted in ${ }^{13} \mathrm{C}$ compared to marine phototrophs due to different isotope systematics between freshwater and marine systems (Oana and Deevey, 1960). Isotope values for soils within the Delta reflect land use, ranging from $\sim-20 \%$ in a corn $\left(\mathrm{C}_{4}\right)$ field to $(\sim-27$ to $-24 \%$ ) in an uncultivated grassland $\left(\mathrm{C}_{3}\right)$. Since the range of $\delta^{13} \mathrm{C}$ values in the bulk Delta sediments we analyzed was small $(-27.4 \pm 0.5 \%$ ) and seasonal and species variability was high (Cloern et al., 2002), it is difficult to conclusively infer the dominant OC source, except perhaps to say that inputs from $\mathrm{C}_{4}$ plants are minor. Nonetheless, the consistently lower values for $\delta^{13} \mathrm{C}$ in the lower density fractions (Fig. 6a) suggest greater proportions of vascular plant $\mathrm{OC}$ in those fractions.

Natural-abundance radiocarbon measurements $\left(\Delta^{14} \mathrm{COC}\right.$ or fraction modern $f_{\mathrm{m}}$ ) add the dimension of "age" to the character of organic matter and help define the residence time and redistribution of OC in rivers and estuaries (Raymond and Bauer, 2001a, b; Blair et al., 2003; Griffith et al., 2010; Lu et al., 2014; McIntosh et al., 2015). In our study, radiocarbon ages of OC of bulk and most density fractions at Elk Slough are modern $\left[\Delta^{14} \mathrm{C} \geq 0 \%\right.$ o $\left.\left(f_{\mathrm{m}} \sim 1\right)\right]$, whereas high-density $>2.5 \mathrm{~g} \mathrm{~cm}^{-3}$ material is depleted in ${ }^{14} \mathrm{C}$ reflecting a more aged character (Fig. 6a). OC in Venice Cut and Nurse Slough, however, is considerably more depleted in ${ }^{14} \mathrm{C}$. Bulk OC and <1.6, 1.6 to 2.0 , and 2.0 to $2.5 \mathrm{~g} \mathrm{~cm}^{-3}$ fractions are similar in radiocarbon isotope values $\left(\Delta^{14} \mathrm{C}-247\right.$ to $-114 \%$ ) but high-density $>2.5 \mathrm{~g} \mathrm{~cm}^{-3}$ fractions are highly ${ }^{14} \mathrm{C}$ depleted $\left(\Delta^{14} \mathrm{C}-339\right.$ and $-382 \%$, for Venice Cut and Nurse Slough, respectively) and hence the oldest (3300 and $3800 \mathrm{yr}$ BP, respectively). Radiocarbon ages of sediments that are "too old" to reflect deposition of recently-biosynthesized ("young") OC require contributions from old OC (often termed "pre-aged" OC) from ter- restrial soil or fossil (rock) OC (Drenzek et al., 2009; Griffith et al., 2010; Blair and Aller, 2012; Douglas et al., 2014; Galy et al., 2015) and/or anthropogenic (petrogenic or fossil fuel combustion) sources (Mitra et al., 2002; Masiello, 2004). Rivers are an important mechanism for redistributing old terrestrial OC (Raymond and Bauer, 2001b; Masiello and Druffel, 2001; Blair and Aller, 2012). In the Rhine and Meuse Rivers, the Ems-Dollard estuary, and the southern North Sea, ${ }^{13} \mathrm{C}$ and ${ }^{14} \mathrm{C}$ compositions of size fractionated suspended particulate matter showed seasonal variations in a mix of OC sources and that a greater proportion of old terrestrial material was associated with coarse $(>20 \mu \mathrm{m})$ material $\left(\delta^{13} \mathrm{C} \sim-26 ; \Delta^{14} \mathrm{C} \sim-500 \%\right.$ ) than fine fractions $\left(\delta^{13}\right.$ $\mathrm{C} \sim-23 ; \Delta^{14} \mathrm{C} \sim-200 \%$ ) (Megens et al., 2001, 2002). In the present study, the relatively unimpacted Elk Slough, which lies north of the city of Sacramento, contains mostly recently biosynthesized OC whereas Venice Cut and Nurse Slough contained higher proportions of older OC. Interestingly, the Nurse Slough site in Suisan Marsh that is not highly influenced by anthropogenic activities had $\Delta^{14} \mathrm{C}$ values indicating sources of aged carbon that could reflect erosion or scouring of deeper marsh sediments or mixing with "older" sources from the surrounding watershed. Overall, there is a progression from $\Delta^{14} \mathrm{C}$-enriched (young) but $\delta^{13} \mathrm{C}$-depleted OC (bulk and density fractions) in Elk Slough to generally more $\Delta^{14} \mathrm{C}$-depleted (older) and $\delta^{13} \mathrm{C}$-enriched OC in Venice Cut and Nurse Slough.

Biomarkers shed additional light on the sources and diagenetic state of river sediment OC. Among the fatty acids analyzed here, short-chain $\left(n-\mathrm{C}_{14}-n-\mathrm{C}_{18}\right)$ FA are biosynthesized by all plants but they are major lipids in freshwater microalgae (Cranwell et al., 1988, 1990; Volkman et al., 1998) and freshwater macroalgae (Dembitsky et al., 1993; Rozentsvet et al., 1995, 2002). Long-chain $\left(n-\mathrm{C}_{24}-n-\mathrm{C}_{28}\right)$ FA are components of epicuticular waxes of terrestrial higher plants (Cranwell et al., 1987; Volkman, 2006) and are abundant in soils. FA compound distributions in Delta sediments - a mix of short-chain and long-chain compounds - confirm heterogeneous sources. Stable carbon isotope values of FA in Delta sediments were lower than TOC, by $\sim 8.1$ to $10.4 \%$ o for the short-chain FA but by $\sim 3.6$ to $5.5 \%$ for the longchain FA (Fig. 6b). All sites showed the same ${ }^{13} \mathrm{C}$ trend: $\delta^{13} \mathrm{C}_{\text {short FA }}<\delta^{13} \mathrm{C}_{\text {long FA }}<\delta^{13} \mathrm{C}_{\mathrm{OC}}$. The offset of $\delta^{13} \mathrm{C}_{F A}$ relative to $\delta^{13} \mathrm{C}_{\mathrm{OC}}$ reflects the $4-8 \%$ isotope fractionation common during autotrophic biosynthesis of acetogenic lipids (in this case FA) vs primary biomass (here represented by TOC) (Hayes, 2001; Pearson, 2010), but the difference between $\delta^{13} \mathrm{C}_{\text {short FA }}$ and $\delta^{13} \mathrm{C}_{\text {long FA }}$ indicates a source distinction. A higher proportion of seston with low $\delta^{13} \mathrm{C}$ values (Cloern et al., 2002) may contribute to the ${ }^{13} \mathrm{C}$-depletion of the short-chain FA pool. Radiocarbon values of FA are more complex and $\Delta^{14} \mathrm{C}_{\text {short FA }}$ indicate predominately modern

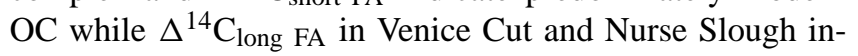
dicate substantial proportions of old OC (Fig. 6b). Shortchain FA could originate from either aquatic or terrestrial 

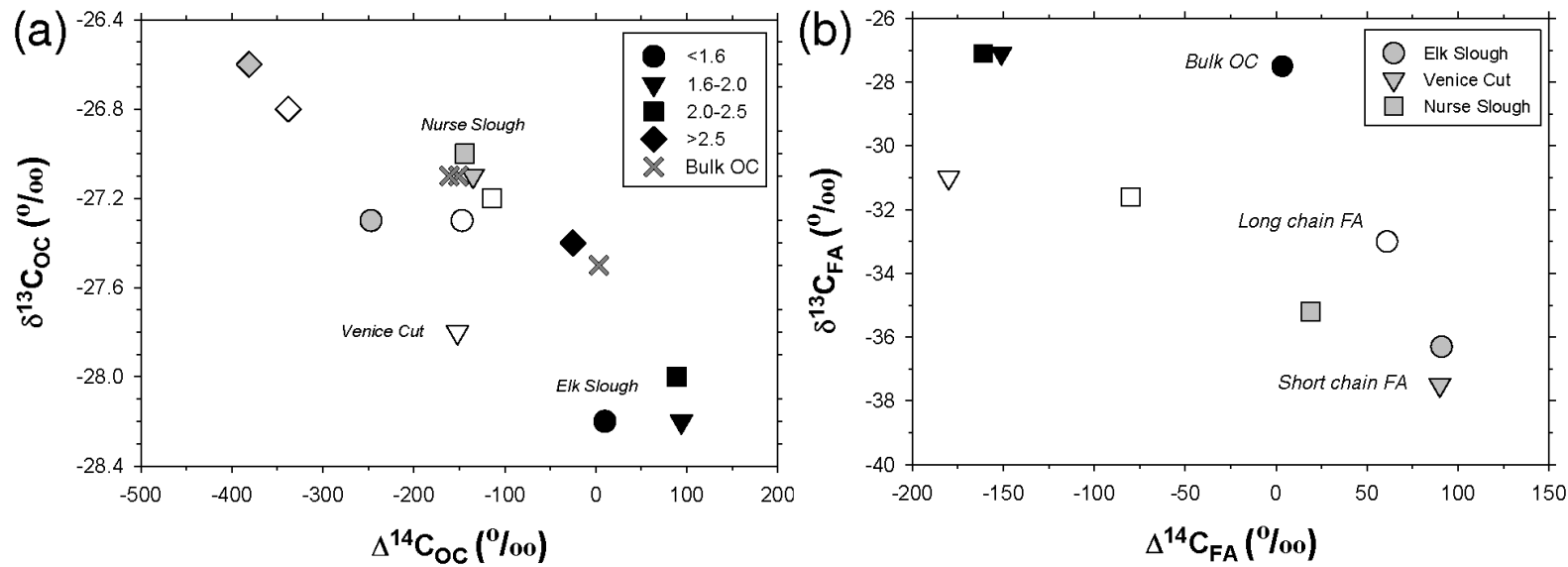

Figure 6. Cross plots of (a) $\delta^{13} \mathrm{C}$ vs. $\Delta^{14} \mathrm{C}$ for OC in Delta bulk sediment and density fractions: black symbols = Elk Slough; white symbols = Venice Cut; gray symbols $=$ Nurse Slough and (b) $\delta^{13} \mathrm{C}$ vs. $\Delta^{14} \mathrm{C}$ for fatty acids in bulk sediments: black symbols $=$ bulk OC; white symbols = long-chain FA; gray symbols = short-chain FA.

plants; the narrow range of $\delta^{13} \mathrm{C}$ does not provide a distinction. Long-chain, vascular plant FA likely reflect storage in soils for some time, but probably do not derive from fossil sources since functionalized lipids like FA, though present at low levels, are mostly lost during diagenesis (Rullkötter and Michaelis, 1990; de Leeuw and Largeau, 1993). Our findings are consistent with isotope compositions of FA in bulk sediments from the Eel Margin and in lower Mississippi River and Mississippi Margin sediments (Wakeham et al., 2009) and in the Delaware Estuary (McIntosh et al., 2015). Longchain FA in Eel sediments had lower ${ }^{13} \mathrm{C}$ values compared to short-chain FA $\left(\delta^{13} \mathrm{C}-32\right.$ and $-25 \%$, respectively). In sediments of the Mississippi River/Margin, the opposite was found: long-chain FA had higher $\delta^{13} \mathrm{C}$ values than shortchain FA ( $-31 \%$ vs. $-37 \%$, respectively). However, like the Sacramento-San Joaquin Delta sediments, short-chain FA in both the Eel and Mississippi River/Margin were modern in age $\left(\Delta^{14} \mathrm{C}+49\right.$ and $+47 \%$, for Eel and Mississippi, respectively) whereas long-chain FA were older $\left(\Delta^{14} \mathrm{C}-109\right.$ and $-91 \%$ for Eel and Mississippi, respectively). This trend is the reverse of that of FA of particulate organic matter in the Delaware Estuary, where short-chain FA were older than long-chain FA, indicating that the riverine algae that are the source of the short-chain FA fix aged dissolved organic carbon (McIntosh et al., 2015). Long-chain FA used to evaluate $\mathrm{OC}$ transport from the Himalayan Mountains and Tibetan Plateau through the Ganges-Bramaputra river system were younger $\left(\Delta^{14} \mathrm{C}-160\right.$ to $-3 \%$ o $)$ than bulk terrestrial biospheric OC $\left(\Delta^{14} \mathrm{C}-878\right.$ to $-63 \%$ ) (Galy et al., 2008; Galy and Eglinton, 2011).

Modern carbon in river sediments and sediments at riverocean margin interfaces must derive from recently biosynthesized aquatic or terrestrial plant biomass. Land plants that fix atmospheric $\mathrm{CO}_{2}$ may have ${ }^{14} \mathrm{C}$ values that are completely modern due to inclusion of post-bomb carbon. The radiocarbon content of freshwater plants varies depending on the reservoir effect of freshwater dissolved inorganic carbon, either $\mathrm{CO}_{2}$ or bicarbonate. If old, dissolved inorganic carbon (e.g., bicarbonate leached from carbonate or evaporitic deposits) is present in freshwater systems, reservoir ages may be longer than in marine systems (Broecker and Walton, 1959; Phillippsen, 2013; Lu et al., 2014; McIntosh et al., 2015) and aquatic plants may be ${ }^{14} \mathrm{C}$-depleted relative to biomass that fixed atmospheric $\mathrm{CO}_{2}$.

Most old carbon in sediments originates from ${ }^{14} \mathrm{C}$ deficient OC remobilized from terrestrial soils or fossil OC from ancient sediments, and much of this export is driven by erosion (e.g., Galy et al., 2015). Soil OC is highly variable in ${ }^{14} \mathrm{C}$ age depending on soil ecosystem and horizon depth, carbon cycling and residence time, land use, and the proportions of modern and fossil carbon, with ages ranging from modern in litterfall and upper horizons to thousands of years in deeper horizons (Richter et al., 1999; Ewing et al., 2006; Trumbore, 2009). In the case of the Delta, surface alluvial soil horizons from grasslands of the Central Valley are modern $\left(\Delta^{14} \mathrm{C}>0\right)$ whereas deeper horizons are significantly older $\left(\Delta^{14} \mathrm{C}-800\right.$ to $-600 \%$ ) depending on whether or not they have been cultivated (Baisden et al., 2002a, b; Ewing et al., 2006). Soil OC typically consists of a rapidly cycling (5-20 yr) low-density fraction of relatively unaltered vascular plant material and a more abundant but slowly cycling mineral-associated component with a mean residence time > $200 \mathrm{yr}$ (Trumbore et al., 1989; Baisden et al., 2002a, b; Ewing et al., 2006; Castanha et al., 2008; Trumbore, 2009; Cerli et al., 2012). The lower region of the Delta, at the confluence of the Sacramento and San Joaquin Rivers, also contains large tracts of peat. Bulk densities of the peat range from $0.2-0.7 \mathrm{~g} \mathrm{~cm}^{-3}$ and their radiocarbon contents ranged from -560 to $-225 \%$ (Ewing et al., 2006; Canuel et al., 2009). Fossil carbon sources 
include OC remobilized from ancient rocks (kerogen) and black carbon (BC). Kerogen is an amorphous network of degraded, polymerized, and crosslinked biomolecules generated during diagenesis (Derenne et al., 1997; de Leeuw and Largeau, 1993; Stankiewicz et al., 2000); BC is a carbonrich, highly aromatized and heterogeneous material that derives from biomass or fossil fuel combustion and sedimentary metamorphism (where alteration of OC has proceeded beyond the kerogen stage) (Masiello, 2004; Dickens et al., 2004), and thus may have modern (biomass) or fossil (ancient sediment) radiocarbon signatures. In lake and marine sediments (Dickens et al., 2004; Veilleux et al., 2009), BC is concentrated in a $<1.6 \mathrm{~g} \mathrm{~cm}^{-3}$ density fraction. Mitra et al. (2002) estimated that $\sim 27 \%$ of the BC load, or up to $25 \%$ of $\mathrm{OC}$, of the Mississippi River is fossil fuel combustionderived. Because both kerogen and $\mathrm{BC}$ are highly refractory with respect to chemical or biological degradation they may cycle between fluvial and sediment and/or soil environments during their transport through drainage basins, especially in environments characterized by rapid channel migration and flooding (Dunne et al., 1998; Aalto et al., 2003; Blair and Aller, 2012). Most particles in rivers are thought to have spent time in soils, floodplain alluvial deposits or wetlands (Reneau and Dietrich, 1991; Gomez et al., 2003; Leithold et al., 2006; Hoffmann et al., 2009).

The age of OC in rivers also varies with the nature of the river and its watershed, and consequently with sediment load (e.g., Raymond and Bauer, 2001b; Leithold et al., 2006; Blair et al., 2003). Small rivers $\left(<10000 \mathrm{~km}^{2}\right.$ watersheds) draining high relief, mountainous (1000-4000 m elevation) areas where thin soils/sedimentary rocks are continuously eroded and there is minimal sediment storage capacity export substantial amounts of old, refractory organic matter. Rivers with lower relief but watersheds that include long-term carbon storage environments such as forests, grasslands, and wetlands can also deliver significant amounts of old OC. In contrast, rivers that integrate large watersheds with diverse geology and land cover/use and with extensive lowland sediment storage areas and floodplains that are dominated by chemical weathering (e.g., the Mississippi-Atchafalaya River System, Gordon and Goñi, 2003; Rosenheim et al., 2013) carry generally younger and less degraded OC. Because the Sacramento and San Joaquin Rivers begin as steep-gradient, high energy streams in the Sierra Nevada Mountains but gradually become larger as numerous tributaries join the mainstems, including those from the Coast Range, they become more quiescent as they flow through the Central Valley and a range of OC sources contributes to the observed elemental and isotopic compositions of river sediments in the Delta.

\section{Conclusions}

Bed sediments in the Sacramento-San Joaquin Rivers contain organic matter unevenly distributed among density frac- tions, similar to other river and continental margin sediments. In general, mass and TOC are concentrated in mesodensity fractions, whereas both low-density material that is rich in woody debris and high-density material that is OC-poor mineral grains are relatively unimportant. At the Elk Slough site, OC is mostly derived from contemporary vegetation, but in both Venice Cut in the San Joaquin River and Nurse Slough in Suisan Marsh substantial amounts of old OC are present, especially in the OC-poor, mineral-rich highest density material. Low river flow, such as during our study period, allows bed sediments to accumulate all density fractions: lowdensity but coarse-grained material consisting of young discrete plant debris, older mesodensity organic-mineral aggregates, and still older organic-poor high-density mineral material. But even under low flow and/or low turbulence conditions, some hydrodynamic sorting may occur whereby the mesodensity fractions become predominant. Overall, this work identifies differences in the source and age composition of organic matter associated with different sediment density fractions in rivers and reveals some of the complex interactions between organic matter and sediments that arise from watershed, hydrology, and hydrodynamic features.

Acknowledgements. Janet Thompson, Francis Parchaso and Byron Richards from the US Geological Survey (Menlo Park CA) assisted with site selection and sample collection. Beth Lerberg (VIMS) provided lab and field assistance and Steve Kuehl and Linda Meneghini assisted in the field. Two anonymous reviewers provided valuable suggestions on the manuscript. This study was supported by the National Science Foundation, Division of Environmental Biology, Ecosystems Program (DEB-0454736 and DEB-0454741) and the Ocean Sciences Division (OCE-0962277). This paper is contribution 3523 of the Virginia Institute of Marine Science, College of William and Mary.

Edited by: J. Middelburg

\section{References}

Aalto, R., Maurice-Bourgoin, L., Dunne, T., Montgomery, D. R., Nittrouer, C. A., and Guyot, J.-L.: Episodic sediment accumulation on Amazonian flood plains influenced by El Niño/Southern Oscillation, Nature, 425, 493-497, 2003.

Adams, W. A.: The effect of organic matter on the bulk and true densities of some uncultivated podzolic soils, J. Soil Sci., 24, 1017, 1973,

Arnarson, T. S. and Keil, R. G.: Organic-mineral interactions in marine sediments studied using density fractionation and $\mathrm{X}$-ray photoelectron spectroscopy, Org. Geochem., 32, 1401-1415, 2001.

Arnarson, T. S. and Keil, R. G.: Changes in organic matter-mineral interactions for marine sediments with varying oxygen exposure times, Geochim. Cosmochim. Ac., 71, 3545-3556, 2007.

Baisden, W. T., Amundson, R., Cook, A. C., and Brenner, D. L.: Turnover and storage of $\mathrm{C}$ and $\mathrm{N}$ in five density fractions from California annual grassland surface soils, Global Biogeochem. Cy., 16, 1117, doi:10.1029/2001GB001822, 2002a. 
Baisden, W. T., Amundson, R., Brenner, D. L., Cook, A. C., Kendall, C., and Harden, J. W.: A multi-isotope C and N modeling analysis of soil organic matter turnover and transport as a function of soil depth in a California annual grassland soil chronosequence, Global Biogeochem. Cy., 16, 1135, doi:10.1029/2001GB001823, 2002b.

Baldock, J. A. and Skjemstad, J. O.: Role of the soil matrix and minerals in protecting natural organic materials against biological attack, Org. Geochem., 31, 697-710, 2000.

Bergamaschi, B. A., Tsamakis, E., Keil, R. G., and Hedges, J. I.: The effect of grain size and surface area on organic matter, lignin and carbohydrate concentration, and molecular compositions in Peru Margin sediments, Geochim. Cosmochim. Ac., 61, 12471260, 1997.

Bianchi, T. A., Galler, J. J., and Allison, M. A.: Hydrodynamic sorting and transport of terrestrially derived organic carbon in sediments of the Mississippi and Atchafalaya rivers, Est. Coast. Shelf Sci., 73, 211-222, 2007.

Blair, N. E. and Aller, R. C.: The fate of terrestrial organic carbon in the marine environment, Annu. Rev. Mar. Sci., 4, 17.1-17.23, 2012.

Blair, N. E., Leithold, E. L., Ford, S. T., Peller, K. A., Holmes, J. C., and Perkey, D. W.: The persistence of memory: The fate of ancient sedimentary organic carbon in a modern sedimentary system, Geochim. Cosmochim. Ac., 67, 63-73, 2003.

Bock, M. J. and Mayer, L. M.: Mesodensity organo-clay associations in a nearshore sediment, Mar. Geol., 163, 65-75, 2000.

Bridge, J. S. and Bennett, S. J.: A model for the entrainment and transport of sediment grains of mixed sizes, shapes, and densities, Water Resour. Res., 28, 337-363, 1992.

Broecker, W. S. and Walton A.: The geochemistry of $\mathrm{C}^{14}$ in freshwater systems., Geochim. Cosmochim. Ac., 16, 15-38, 1959.

Canuel, E. A.: Relations between river flow, primary production and fatty acid composition of particulate organic matter in San Francisco and Chesapeake Bays: a multivariate approach, Org. Geochem., 32, 563-583, 2001.

Canuel, E. A., Lerberg, E. J., Dickhut, R. M., Kuehl, S. S., Bianchi, T. S., and Wakeham, S. G.: Changes in sediment and organic carbon accumulation in a highly-disturbed ecosystem: The Sacramento-San Joaquin River Delta, (California, USA.), Mar. Pollut. Bull., 59, 154-163, 2009.

Castanha, C., Trumbore, S., and Amundson, R.: Methods of separating soil carbon pools affect the chemistry and turnover time of isolated fraction, Radiocarbon, 50, 83-97, 2008.

Cerli, C., Celi, L., Kalbitz, K., Guggenberger, G., and Kaiser, K.: Separation of light and heavy organic matter fractons in soil - Testing for proper density cut-off and dispersion level, Geoderma, 170, 403-416, 2012.

Cloern, J. E., Canuel, E. A., and Harris, D.: Stable carbon and nitrogen isotope composition of aquatic and terrestrial plants of the San Francisco Bay estuarine system, Limnol. Oceanogr., 47, 713-729, 2002.

Conomos, T. J., Smith, R. E., and Gartner, J. W.: Environmental setting of San Francisco Bay, in: Temporal Dynamics of an Estuary: San Francisco Bay, edited by: Cloern, J. E. and Nichols, F. H., Hydrobiologica, 129, 1-12, 1985.

Cranwell, P. A., Eglinton, G., and Robinson, N.: Lipids of aquatic organisms as potential contributors to lacustrine sediments - II, Org. Geochem., 11, 513-527, 1987.
Cranwell, P. A., Creighton, M. E., and Jaworski, G. H. M.: Lipids of four freshwater chrysophytes, Phytochem., 27, 1053-1059. 1988.

Cranwell, P. A., Jaworski, G. H. M., and Bickley, H. M.: Hydrocarbons, sterols, esters, and fatty acids in six freshwater chlorophytes, Phytochem., 29, 145-151, 1990.

Crow, S. E., Swanston, C. W., Lajtha, K., Brooks, J. R., and Keirstead, H.: Density fractionation of forest soils: methodological questions and interpretation of incubation results and turnover time in an ecosystem context, Biogeochem., 85, 69-90, 2007.

Dade, W. B. and Friend, P. F.: Grain size, sediment transport regime, and channel slope in alluvial rivers, J. Geol., 106, 661-676, 1998.

de Leeuw, J. W. and Largeau, C.: A review of macro-molecular organic compounds that comprise living organisms and their role in kerogen, coal, and petroleum formation, in: Organic Geochemistry, edited by: Engel, M. H. and Macko, S. A., Plenum Press, New York, 23-72, 1993.

Dembitsky, V. M., Rezanka, T., and Rozentsvet, O. A.: Lipid composition of three macrophytes from the Caspian Sea, Phytochem., 33, 1015-1019, 1993.

Derenne, S., Largeau, C., Casadevall, E., Berkaloff, C., and Rousseau, B.: Chemical evidence of kerogen formation in source rocks and oil shales via selective preservation of thin resistant outer walls of microalgae: Origin of ultralaminae, Geochim. Cosmochim. Ac., 55, 1041-1050, 1993.

Dickens, A. F., Gélinas, Y., Masiello, C. A., Wakeham, S. G., and Hedges, J. I.: Reburial of fossil carbon in marine sediments, Nature, 427, 336-339, 2004.

Dickens, A. F., Baldock, J. A., Smernik, R. J., Wakeham, S. G., Arnarson, T. A., Gélinas, Y., and Hedges, J. I.: Solid state ${ }^{13} \mathrm{C}$ NMR analysis of size and density fractions of marine sediments. Insights into carbon sources and preservation mechanisms, Geochim. Cosmochim. Ac., 70, 666-686, 2006.

Douglas, P. M. J., Pagani, M., Eglinton, T. I., Brenner, M., Hodell, D. A., Curtis, J. H., Ma, K.F., and Breckenridge, A.: Preaged plant waxes in tropical lake sediments and their influence on the chronology of molecular paleoclimate records, Geochim. Cosmochim. Ac., 141, 346-364, 2014.

Drenzek, N. J., Hughen, K. A., Montluçon, D. B., Southon, J. R., dos Santos, G. M., Druffel, E. R. M., Giosan, L., and Eglinton, T. I.: A new look at old carbon in active margin sediments, Geol., 37, 239-242, 2009.

Dunne, T., Mertes, L. A. K., Meade, R. H., Richey, J. E., and Frosberg, B. R.: Exchanges of sediment between the flood plain and channel of the Amazon River in Brazil, Geol. Soc. Am. Bull., 110, 450-467, 2003.

Eglinton, T. I., Benitez-Nelson, B. C., Pearson, A., McNichol, A., Bauer, J. E., and Druffel, E. R. M.: Variability in radiocarbon ages of individual organic compounds from marine sediments, Science, 277, 796-799, 1997.

Ewing, S. A., Sanderman, J., Baisden, T. W., Wang, Y., and Amundson, R.: Role of large-scale soil structure in organic carbon turnover; evidence from California grassland soils, J. Geophys. Res., 111, nGO3012, doi:10.1029/2006JG000174, 2006.

Galy, V. and Eglinton, T.: Protracted storage of biospheric carbon in the Ganges-Brahmaputra basin, Nature Geosci., 4, 843-847, 2011. 
Galy, V., France-Lanord, C., and Lartiges B.: Loading and fate of particulate organic carbon from the Himalaya to the GangaBramaputra delta, Geochim. Cosmochim. Ac., 72, 1767-1787, 2008.

Galy, V., Peucker-Ehrenbrink, B., and Eglinton, T.: Global carbon export from the terrestrial biosphere controlled by erosion, Nature, 521, 204-207, 2015.

Golchin, A., Oades, J. M., Skjemstad, J. O., and Clarke, P.: Study of free and occluded particulate organic-matter in soils by solid state ${ }^{13} \mathrm{C} \mathrm{C}_{p}$ /MAS NMR pectroscopy and scanning electron microscopy, Aust. Soil Res., 32, 285-309, 1994.

Gomez, B., Brackley, H. L., Hicks, D. M., Neff, H., and Rogers, K. M.: Organic carbon in floodplain alluvium: Signature of historic variations in erosion processes associated with deforestation, Waipaoa River basin, New Zealand, J. Geophys. Res., 109, F04011, doi:10.1029/2004JF000154, 2004.

Gordon, E. S. and Goñi, M. A.: Sources and distributions of terrigenous organic matter delivered by the Atchafalaya River to sediments in the northern Gulf of Mexico, Geochim. Cosmochim. Ac., 67, 2359-2375, 2003.

Gordon, E. S. and Goñi, M. A.: Controls on the distribution and accumulation of terrigenous organic matter in sediments from the Mississippi and Atchafalaya River margin, Mar. Chem., 92, 331-352, 2004.

Griffith, D. R., Martin, W. T., and Eglinton, T. I.: The radiocarbon age of organic carbon in marine surface sediments, Geochim. Cosmochim. Ac., 74, 6788-6800, 2010.

Hassanzadeh, Y.: Hydraulics of Sediment Transport, Hydrodynamics - Theory and Model, edited by: Zheng, J.-H., ISBN: 978-953-51-0130-7, InTech, available at: http://www. intechopen.com/books/hydrodynamics-theory-and-model/ hydraulics-of-sediment-transport, 2012.

Hayes, J. M.: Fractionation of the isotopes of carbon and hydrogen in biosynthetic processes, in: Stable Isotope Geochemistry, edited by: Valley, J. W. and Cole, D. R., Rev. Mineral. Geochem., 43, 225-278, 2001.

Hedges, J. I. and Keil, R. G.: Sedimentary organic matter preservation: an assessment and speculative synthesis, Mar. Chem., 49, 81-115, 1995.

Hedges, J. I. and Oades, M.: A comparative study of marine and soil geochemistry, Org. Geochem., 27, 319-361, 1997.

Herbold, B. and Moyle, P. B.: The ecology of the Sacramento-San Joaquin Delta: a community profile, US Fish Wildl. Serv. Biol. Rep. 85, xi + 106 pp., 1989.

Hodson, M. E., Langan, S. J., and Meriau, S.: Determination of mineral surface area in relation to the calculation of weathering rates, Geoderma, 83, 35-54, 1998.

Hoffmann, T., Glatzel, S., and Dikau, R.: A carbon storage perspective on alluvial sediment storage in the Rhine catchment, Geomorphol., 108, 127-137, 2009.

Horowitz, A. J. and Elrick, K. A.: The relation of stream sediment surface area, grain size and composition to trace element chemistry, Appl. Geochem., 2, 437-451, 1987.

Jassby, A. D. and Cloern, J. E.: Organic matter sources and rehabilitation of the Sacramento-San Joaquin Delta (California, USA), Aquat. Conserv., 10, 323-352, 2000.

Jepson, R., Roberts, J., and Lick, W.: Effects of bulk density on sediment erosion rates, Water Air Soil Pollut., 99, 21-31, 1997.
Kaiser, M. and Berhe, A. A.: How does sonication affect the mineral and organic constituents of soil aggregates? - A review, J. Plant Nutr. Soil Sci., 177, 479-475, 2014.

Karlen, I., Olsson, I. U., Kallburg, P.- and Kilici, S.: Absolute determination of the activity of two ${ }^{14} \mathrm{C}$ dating standards, Arkiv Geofysik, 4, 465-471, 1964.

Keil, R. G. and Mayer, L. M.: Mineral matrices and organic matter, in: Treatise on Geochemistry, edited by: Falkowski, P. G. and Freeman, K. H., Elsevier, 12, 337-359, 2014.

Keil, R. G., Tsamakis, E., Fuh, C. B., Giddings, J. C., and Hedges, J. I.: Mineralogical and textural controls on the organic composition of coastal marine sediments: hydrodynamic separation using SPLITT-fractionation, Geochim. Cosmochim. Ac., 54, 879-893, 1994a.

Keil, R. G., Montluçon, D. B., Prahl, F. G., and Hedges, J. I.: Sorptive preservation of labile organic matter in marine sediments, Nature, 370, 549-552, 1994b.

Keil, R. G., Mayer, L. M., Quay, P. D., Richey, J. E., and Hedges, J. I.: Loss of organic matter from riverine particles in deltas, Geochim. Cosmochim. Ac., 61, 1507-1511, 1997.

Keil, R. G., Tsamakis, E., Giddings, and J. C., Hedges, J. I.: Biochemical distributions (amino acids, neutral sugars, and lignin phenols) among size-classes of modern marine sediments from the Washington Margin, Geochim. Cosmochim. Ac., 62, 13471364, 1998.

Leithold, E. L., Blair, N. E., and Perkey, D. W.: Geomorphologic controls on the age of particulate organic carbon from small mountainous and upland rivers, Global Biogeochem. Cy., 20, GB3022, doi:10.1029/2005GB002677, 2006.

Lu, Y. H., Bauer, J. E., Canuel, E. A., Chambers, R. M., Yamashita, Y., Jaffé, R., and Barrett, A.: Effects of land use on sources and ages of inorganic and organic carbon in temperate headwater streams, Biogeochemistry, 119, 275-292, 2014.

Masiello, C. A.: New directions in black carbon organic geochemistry, Mar. Chem., 92, 201-213, 2004.

Masiello, C. A. and Druffel, E. R. M.: Carbon isotope geochemistry of the Santa Clara River, Global Biogeochem. Cy., 15, 407-416, 2001.

Mayer, L. M.: Relationships between mineral surfaces and organic carbon concentrations in soils and sediments, Chem. Geol., 114, 347-363, 1994a.

Mayer, L. M.: Surface area control of organic carbon accumulation in continental shelf sediments, Geochim. Cosmochim. Ac., 58, 1271-1284, 1994b.

Mayer, L. M.: Extent of coverage of mineral surfaces by organic matter in marine sediments, Geochim. Cosmochim. Ac., 63, 207-215, 1999.

Mayer, L. M., Jumars, P. A., Taghon, G. L., Macko, S. A., and Trumbore, S.: Low-density particles as potential nitrogenous foods for benthos, J. Mar. Res., 51, 373-389, 1993.

Mayer, L. M., Schick, L. L., Hardy, K. R., Wagai, R., and McCarthy, J.: Organic matter in small mesopores in sediments and soils, Geochim. Cosmochim. Ac., 68, 3863-3872, 2004.

McIntosch, H. A., McNichol, A. P., Xu, L., and Canuel, E. A.: Source-age dynamics of estuarine particulate organic matter using fatty acid $\delta^{13} \mathrm{C}$ and $\Delta^{14} \mathrm{C}$ composition, Limnol. Oceanogr., 60, 611-628, 2015.

McNichol, A.P., Osborne, E.A., Gagnon, A. R., Fry, B., and Jones,G. A.: TIC, TOC, DIC, DOC, PIC, POC - unique aspects 
in the preparation of oceanographic samples for ${ }^{14} \mathrm{CAMS}$, Nucl. Instrum. Methods, B, 92, 162-165, 1994.

Megens, L., van der Plicht, J., and de Leeuw, J. W.: Temporal variations in ${ }^{13} \mathrm{C}$ and ${ }^{14} \mathrm{C}$ concentrations in particulate organic matter from the southern North Sea, Geochim. Cosmochim. Ac., 65, 2899-2911, 2001.

Megens, L., van der Plicht, J., de Leeuw, J. W., and Smedes, F.: Stable carbon and radiocarbon isotope compositions of particle size fractions to determine origins of sedimentary organic matter in an estuary, Org. Geochem., 33, 945-952, 2002.

Milliman, J. D. and Farnsworth, K. L.: River Discharge to the Coastal Ocean, Cambridge Univ. Press., 384 pp., 2011.

Mitra, S., Bianchi, T. S., McKee, B. A., and Sutula, M.: Black carbon from the Mississippi River: quantities, sources, and potential implications for the global carbon cycle, Environ,. Sci. Technol., 36, 2296-2302, 2002.

Nilsen, E. B. and Delaney, M. L.: Factors influencing the biogeochemistry of sedimentary carbon and phosphorus in the Sacramento-San Joaquin Delta, Estuaries, 28, 653-663, 2005.

Oana, S. and Deevey, E. S.: Carbon 13 in lake waters, and its possible bearing on paleolimnology, Am. J. Sci. A, 258, 253-272, 1960.

Pearson, A.: Pathways of carbon assimilation and their impact on organic matter values of $\delta^{13} \mathrm{C}$, edited by: Timmis, K., Springer-Verlag, Berlin, 143-156, doi:10.1007/978-3-54077587-4_9, 2010.

Philippsen, B.: The freshwater reservoir effect in radiocarbon dating, Heritage Sci., 1, 24, doi:10.1186/2050-7445-1-24, 2013.

Prahl, F. G.: Chemical evidence of differential particle dispersal in the southern Washington coastal environment, Geochim. Cosmochim. Ac., 49, 2533-2539, 1985.

Ransom, B., Kim, D., Kastner, M., and Wainwright, S.: Organic matter preservation on continental slopes: importance of mineralogy and surface area, Geochim. Cosmochim. Ac., 62, 1329$1345,1998$.

Raymond, P. A. and Bauer, J. E.: Riverine export of aged terrestrial organic matter to the North Atlantic Ocean, Nature, 409, 497500, 2001a.

Raymond, P. A. and Bauer J. E.: Use of ${ }^{14} \mathrm{C}$ and ${ }^{13} \mathrm{C}$ natural abundances for evaluating riverine, estuarine and coastal DOC and POC sources and cycling: a review and synthesis, Org. Geochem., 32, 469-485, 2001b.

Reed, D. J.: Understanding tidal marsh sedimentation in the Sacramento-San Joaquin Delta, California, J. Coast. Res., 36, 605-611, 2002.

Reneau, S. L. and Dietrich, W. E.: Erosion rates in the southern Oregon Coast Range: Evidence for an equilibrium between hillslope erosion and sediment yield, Earth Surf. Proc. Landforms, 16, 307-322, 1991.

Richter, D. D., Markewitz, D., Trumbore, S. E., and Wells, G. G.: Rapid accumulation and turnover of soil carbon in a reestablishing forest, Nature, 400, 56-58, 1999.

Rosenheim, B. E., Roe, K. M., Roberts, B. J., Kolker, A. S., Allison, M. A., and Johannesson, K. H.: River discharge influences on particulate organic carbon age structure in the Mississippi/Atchafalaya River System, Global Biogeochem. Cy., 27, 154-166, 2013.
Rozentsvet, O. A., Dembitsky, and N. M., and Zhuicova, V. S.: Lipids from macrophytes of the middle Volga, Phytochem., 38, 1209-1213, 1995.

Rozentsvet, O. A., Saksonov, S. V., and Dembitsky, V. M.: Hydrocarbons, fatty acids, and lipids of freshwater grasses of the Potamogetonaceae family, Biochemistry-USSR +, 67, 422-429, 2002.

Rühlmann J., Körschens, M., and Greafe, J.: A new approach to calculate the particle density of soils considering properties of the soil organic matter and the mineral matrix, Geoderma, 130, 272-283, 2006.

Rullkötter, J. and Michaelis, W.: The structure of kerogen and related materials. A review of recent progress and future trends, Org. Geochem., 16, 829-852, 1990.

Sampere, T. P., Bianchi, T. S., Wakeham, S. G., and Allison, M. A.: Sources of organic matter in surface sediments of the Louisiana continental margin: effects of primary depositional/transport pathways and Hurricane Ivan, Cont. Shelf Res., 28, 2472-2487, 2008.

Schoellhamer, D. H., Wright, S. A., and Drexler, J. Z.: Conceptual model of sedimentation in the Sacramento-San Joaquin River Delta, San Francisco Estuary Watershed Sci., 10, 1-25, 2012.

Schoellhamer, D. H., Wright, S. A., and Drexler, J. Z.: Adjustment of the San Francisco estuary and watershed to decreasing sediment supply in the 20th century, Mar. Geol., 345, 63-71, 2013.

Schreiner, K. M., Bianchi, T. S., Eglinton, T. I., Allison, M. A., and Hanna, A. J.: Sources of terrigenous inputs to surface sediments of the Colville River Delta and Simpson's Lagoon, Beaufort Sea, Alaska, J. Geophys. Res.-Biogeo., 118, 808-824, 2013.

Shang, C. and Tiessen, H.: Sequential versus parallel density fractionation of silt-sized organomineral complexes of tropical soils using metatungstate, Soil Biol. Biochem., 33, 259-262, 2001.

Sollins, P., Swanston, C., Kleber, M., Filley, T. Kramer, M., Crow, S., Caldwell, B. A., Lajtha, K., and Bowden, R.: Organic C and $\mathrm{N}$ stabilization in a forest oil: Evidence from sequential density fractionation, Soil. Biol Biochem., 38, 3313-3324, 2006.

Stankiewicz, B. A., Briggs, D. E. G., Michels, R., Collinson, M.E., Flannery, M. B., and Evershed, R. P.: Alternative origin of aliphatic polymer in kerogen, Geology, 28, 559-562, 2000

Stuiver, M.: Workshop on ${ }^{14} \mathrm{C}$ data reporting, Radiocarbon, 22, 964-966, 1980.

Stuiver M. and Polach, H. A.: Discussion: Reporting of $14 \mathrm{C}$ data, Radiocarbon, 19, 355-363, 1997.

Trumbore, S. E.: Radiocarbon and soil carbon dynamics, Annu. Rev. Earth Pl. Sc., 37, 47-66, 2009.

Trumbore, S. E., Vogel, and J. S., and Southon, J. R.: AMS ${ }^{14} \mathrm{C}$ measurements of fractionated soil organic matter: An approach to deciphering the soil carbon cycle, Radiocarbon, 31, 644-654, 1989.

Veilleux, M.-H., Dickens, A. F., Brandes, J., and Gélinas Y.: Density separation of combustion-derived soot and petrogenic graphitic black carbon: Quantification and isotopic characterization, in: From Deep-Sea to Coastal Zones: Methods and Techniques For Studying Paleoenvironments, IOP Conf. Series, Earth and Environ. Sci., 5, 1-9, 2010.

Volkman, J. K.: Lipid markers for marine organic matter, in: The Handbook of Environmental Chemistry, vol. 2, Reactions and Processes, Part N, Marine Organic Matter: Biomarkers, Isotopes 
and DNA, edited by: Hutzinger, O. and Volkman, J. K., Springer, Berlin, 27-70, 2006.

Volkman, J. K., Barrett, S. M., Blackburn, S. I., Mansouri, M. P., Sikes, E. L., and Gelin, F.: Microalgal biomarkers: A review of recent research developments, Org. Geochem., 29, 1163-1169, 1998.

von Reden, K. F., Schneider, R. F., McNichol, A. P., and Pearson, A.: ${ }^{14}$ C-AMS measurements of $<100 \mu \mathrm{g}$ samples with a highcurrent system, Radiocarbon, 40, 247-253, 1998.

Wakeham, S. G., Lee, C, Hedges, J. I., Hernes, P. J., and Peterson, M. L.: Molecular indicators of diagenetic status in marine organic matter, Geochim. Cosmochim. Ac., 61, 5363-5369, 1997.

Wakeham, S. G., McNichol, A. P., Kostka, J., and Pease, T. K.: Natural abundance radiocarbon as a tracer of assimilation of petroleum carbon by bacteria in salt marsh sediments, Geochim. Cosmochim. Ac., 70, 1761-1771, 2006.

Wakeham, S. G., Canuel, E. A., Lerberg, E. J., Mason, P., Sampere, T., and Bianchi T.: Partitioning of organic matter in continental margin sediments among density fractions, Mar. Chem., 115, 211-225, 2009.
Waterson, E. J. and Canuel, E. A.: Sources of sedimentary organic matter in the Mississippi River and adjacent Gulf of Mexico as revealed by lipid biomarker and $\delta^{13} \mathrm{C}_{\mathrm{TOC}}$ analyses, Org. Geochem., 39, 422-439, 2008.

Weiler, R. R. and Mills, A. A.: Surface properties and pore structure of marine sediments, Deep-Sea Res., 12, 511-529, 1965.

Wright, S. A., and Schoellhamer, D. H.: Trends in the sediment yield of the Sacramento River, California, 1957-2001, San Francisco Estuary and Watershed Science, 2, 1-14, 2004.

Wright, S. A. and Schoellhamer, D. H.: Estimating sediment budgets at the interface between rivers and estuaries with application to the Sacramento-San Joaquin River Delta, Water Resour. Res. 41, W09428, doi:10.1029/2004WR003753, 2005. 